\title{
Cultural Resources Survey of Antiquities Permit Portions of the Orion Refurbishment Project in Midland and Mitchell Counties,
} Texas

Tony Scott

Follow this and additional works at: https://scholarworks.sfasu.edu/ita

Part of the American Material Culture Commons, Archaeological Anthropology Commons, Environmental Studies Commons, Other American Studies Commons, Other Arts and Humanities Commons, Other History of Art, Architecture, and Archaeology Commons, and the United States History Commons

Tell us how this article helped you.

This Article is brought to you for free and open access by the Center for Regional Heritage Research at SFA ScholarWorks. It has been accepted for inclusion in Index of Texas Archaeology: Open Access Gray Literature from the Lone Star State by an authorized editor of SFA ScholarWorks. For more information, please contact cdsscholarworks@sfasu.edu. 


\section{Cultural Resources Survey of Antiquities Permit Portions of the Orion Refurbishment Project in Midland and Mitchell Counties, Texas}

\section{Creative Commons License}

(c) (1) (8)

This work is licensed under a Creative Commons Attribution-NonCommercial 4.0 International License 


\section{GRAY $\&$ PAPE HER I TA GE MANAGEMENT}

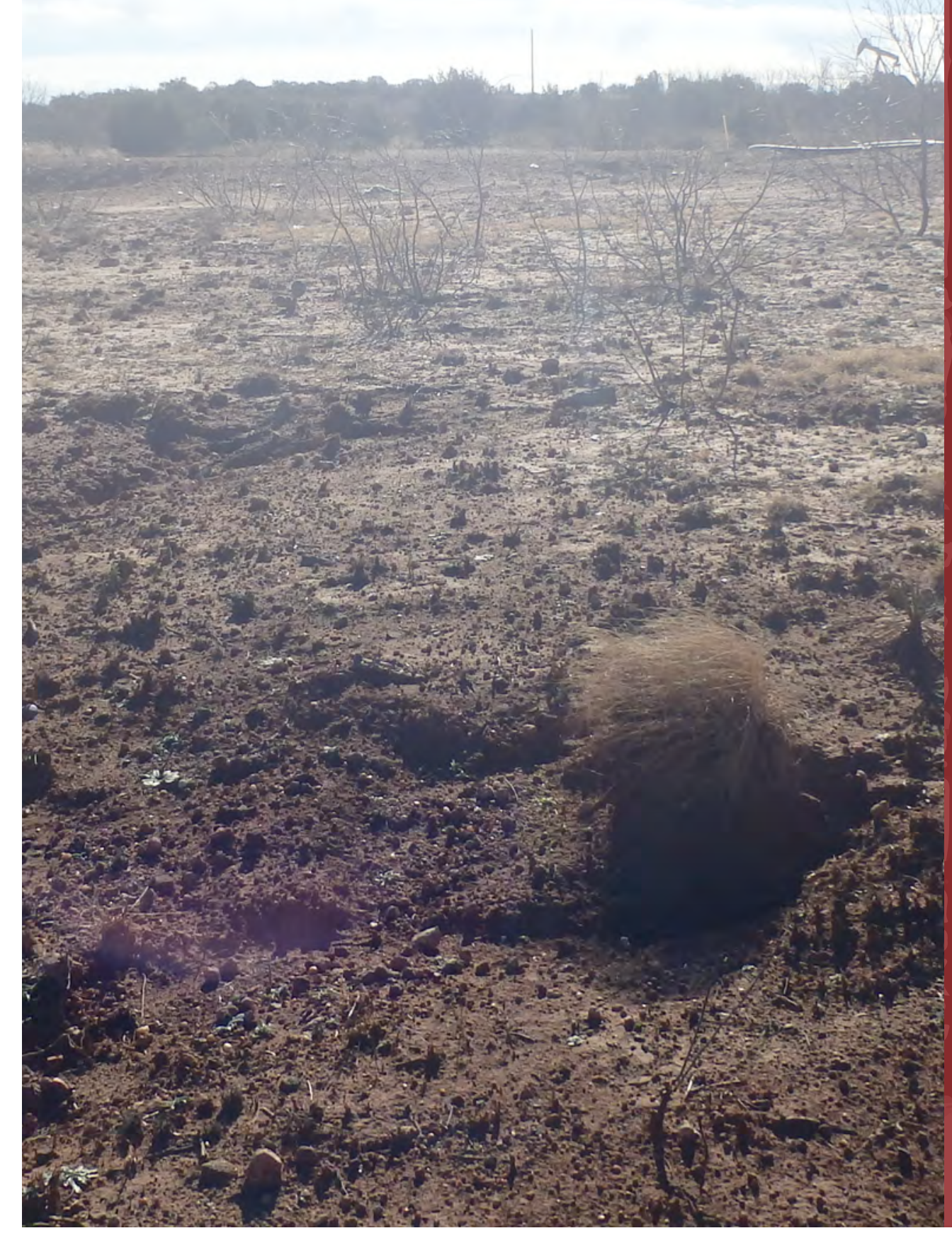

Texas Antiquities Permit \#8677

Cultural Resources Survey of Antiquities Permit Portions of the Orion Refurbishment Project in Midland and Mitchell Counties, Texas

\section{PREPARED FOR: \\ BIO-WEST, Inc. \\ 1018 Frost Street}

Rosenberg, Texas 77471

\section{PREPARED BY:} Gray \& Pape, Inc.

110 Avondale Street Houston, Texas 77006 


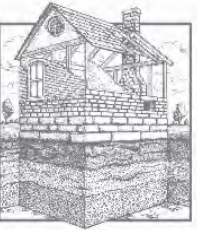

\section{GRAY $\&$ PAPE \\ HERITAGE MANAGEMENT}

Project No. 18-72324.001

Cultural Resources Survey of Antiquities Permit Portions of the Orion Refurbishment Project in Midland and Mitchell

Counties, Texas

Texas Antiquities Permit \#8677

Prepared for:

BIO-WEST, Inc.

1018 Frost Street

Rosenberg, Texas 77471

(832) 595-9064

Prepared by:

Tony Scott

Gray \& Pape, Inc.

110 Avondale Street

Houston, Texas 77006

(713) 541-0473

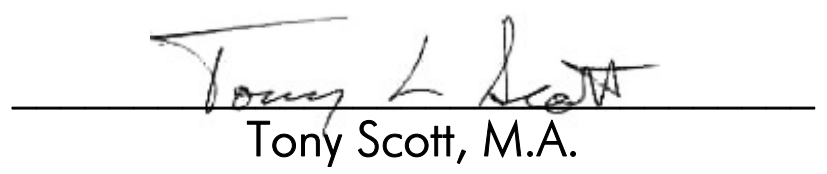

Sr. Principal Investigator

January 10, 2020 


\section{ABSTRACT}

Gray and Pape, Inc., performed an intensive pedestrian cultural resources survey of the Area of Potential Effects of permitted segments of proposed pipeline refurbishment located in Midland and Mitchell Counties, Texas. To date, no federal permitting has been identified for the project. However, approximately 3.2 kilometers (2 miles) of the project area are located on lands owned by the City of Midland and the City of Colorado City, and will be reviewed under the Texas Antiquities Code (Texas Natural Resource Code, Title 9, Chapter 191), Permit number 8677. The area surveyed amounts to approximately 20 hectares (50 acres) of survey corridor, which is considered the Area of Potential Effects.

A records and literature review of the project location prior to survey identified two previously recorded archaeological sites and two previously conducted surveys within a 1.6-kilometer (1-mile) radius of the project. Fieldwork was conducted in January and March of 2019. The project required 156-person hours to complete and involved archaeological reconnaissance and shovel testing throughout the entire Area of Potential Effects. A total of 116 shovel tests were excavated along current and previously planned routes, of which 10 were positive for cultural materials.

One new previously unrecorded site was identified as a result of survey. Site 41 MD58 consists of a lowdensity surface and buried lithic scatter of a limited number of artifacts and artifact types. The surface of the resource area showed clear disturbance from the adjacent pipeline right-of-way and agricultural activities. A portion of the site was in the process of being disturbed at the time of site delineation by pipeline activities unrelated to the current project consisting of an open trench and associated spoil.

Shovel tests within the site showed a lack of integrity primarily as a result of natural and artificial processes resulting in the dispersion of artifacts. The site did not contain temporally or culturally diagnostic artifacts and no artifacts were collected. Nor were any cultural features or historic-age standing resources encountered in the field. Based on the paucity of artifacts, lack of diagnostic materials, and lack of integrity, the site portion located within the Area of Potential Effects is recommended not eligible for State Antiquities Landmark or National Register status. Gray \& Pape, Inc. recommends no additional archaeological work for the site or surveyed portions of the project detailed in this report. However, Gray \& Pape, Inc. recommends that an unanticipated discoveries plan be put into place in the event that discoveries take place during construction. Gray \& Pape, Inc. submitted project records to the Center of Archaeological Studies at Texas State University. 


\section{TABLE OF CONTENTS}

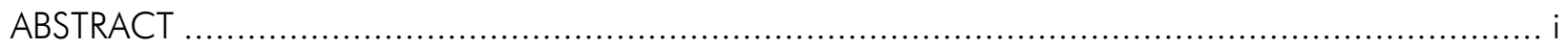

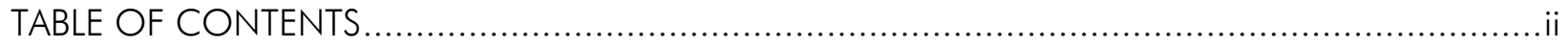

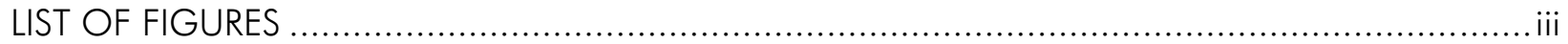

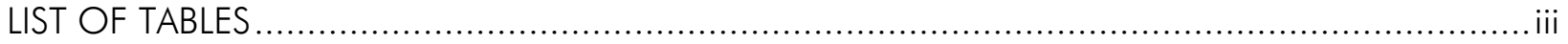

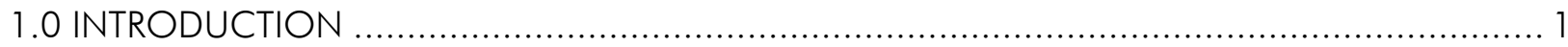

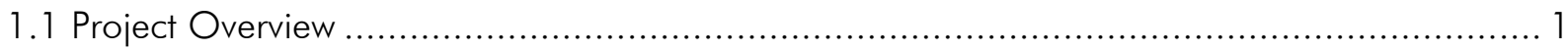

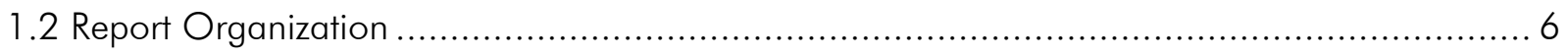

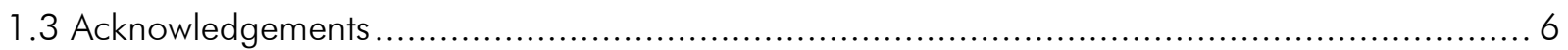

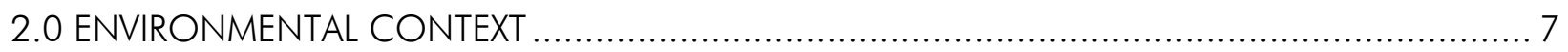

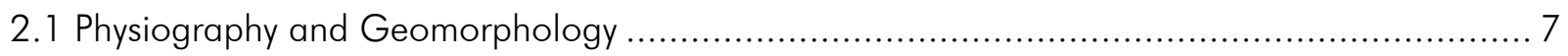

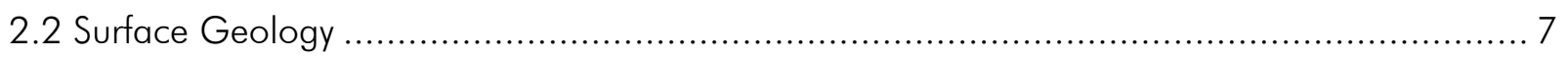

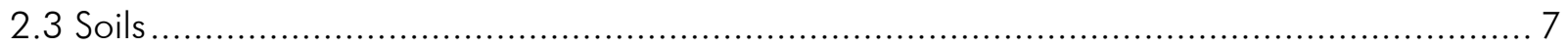

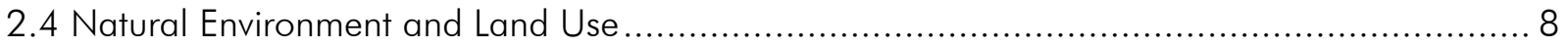

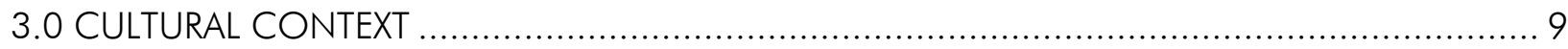

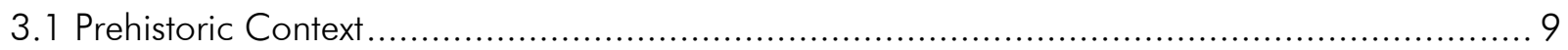

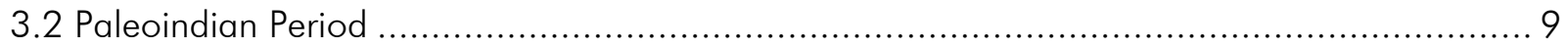

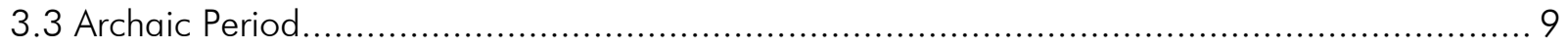

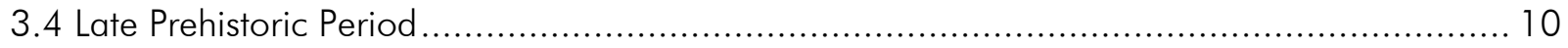

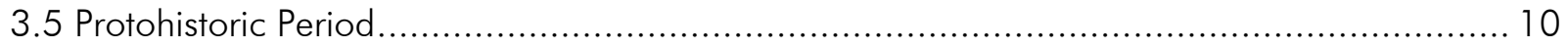

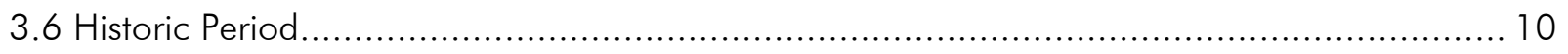

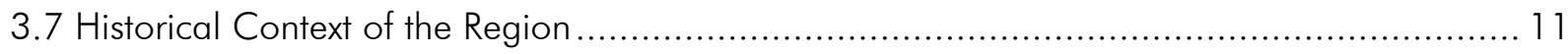

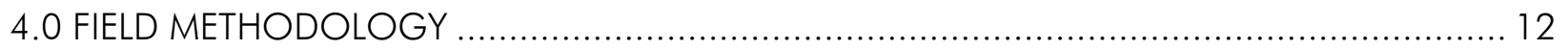

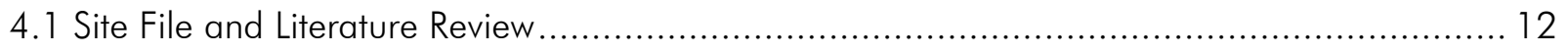

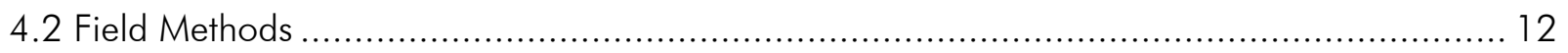

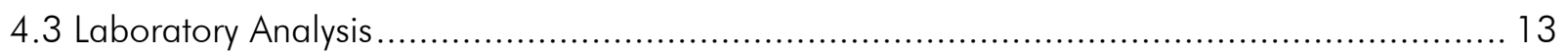

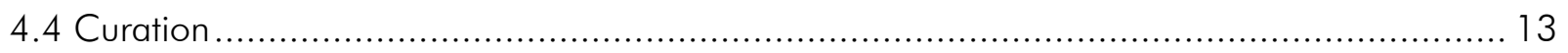

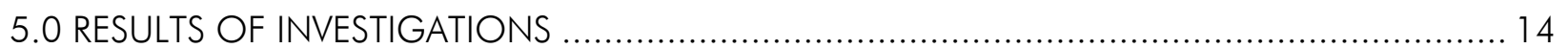

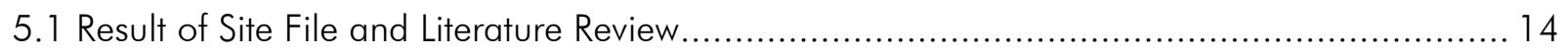

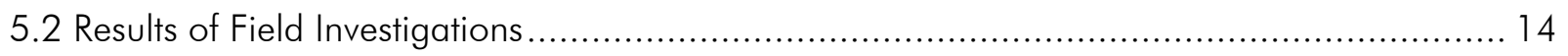

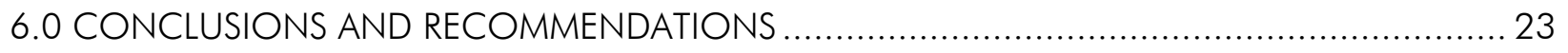

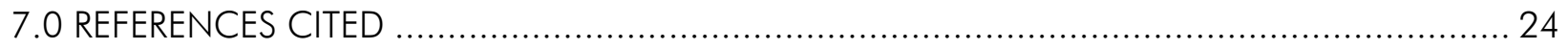




\section{LIST OF FIGURES}

Figure 1-1. Permit area locations in Midland and Mitchell Counties, Texas. ................................ 2 Figure 1-2. Portions of project centerline located on City of Midland property in Midland County, Texas.

Figure 1-3. Portions of project centerline located on City of Colorado City property in Mitchell County,

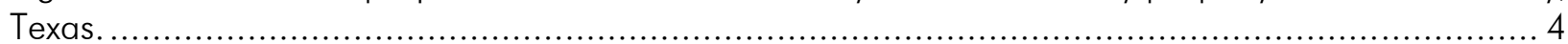

Figure 1-4. Portions of project centerline located on City of Colorado City property in Mitchell County,

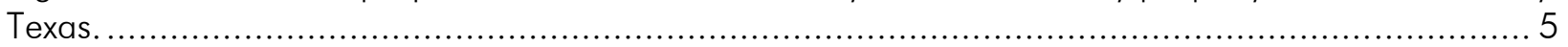

Figure 5-1. Overview of field conditions in Tract 6926-MI-248A. View is to the west................... 15

Figure 5-2.Overview of field conditions in Tract 6984-MD-46. View is to the east. ..................... 15 Figure 5-3. Ongoing pipeline work being conducted within the current corridor at the time of survey in

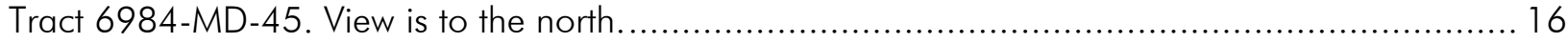

Figure 5-4. Overview of the northern half of Site 41MD58. View is to the northeast. .................... 18 Figure 5-5. Overview of the southern half of Site 41MD58. View is to the southwest................... 18

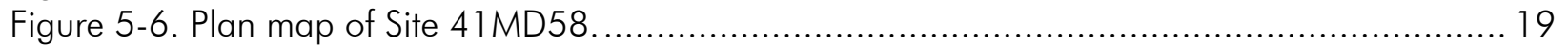
Figure 5-7. Biface recorded on the surface of Site 41 MD58............................................ 21 Figure 5-8. Three limestone FCR fragments and 1 chert flake observed in Shovel Test A1 + 10W +

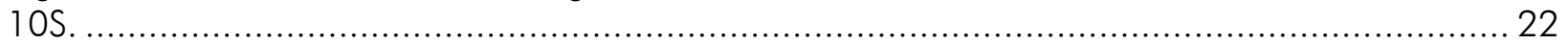
Figure 5-9. Overview of active pipeline work taking place within the southern half of Site 41MD58 at the time of delineation survey. View is to the east. 22

\section{LIST OF TABLES}

Table 2-1. Geologic Groups/Formations Intersected by the Project. ....................................... 7

Table 2-2. Soils within the Project Area. ................................................................... 7

Table 5-1. Provenience of Subsurface Materials Identified within Site 41MD58.......................... 20

Table 5-2. Artifact Distribution Observed at Site 41MD58. ................................................... 21 


\subsection{INTRODUCTION}

Bio-West, Inc. (BIO-WEST), of Rosenberg, Texas, on the behalf of their client, Magellan Crude Oil Pipeline Company, L.P. (Magellan), contracted with Gray \& Pape, Inc. (Gray \& Pape), of Houston, Texas, to perform an intensive pedestrian cultural resources survey of approximately 3.2 kilometers $(2$ miles) of project centerline located on City owned property in Midland and Mitchell Counties, Texas.

To date, no federal permitting has been identified for the project. Approximately 3.2 kilometers (2 miles) of centerline will involve property under the control of local governmental entities (the City of Midland and the City of Colorado City); thus, a Texas Antiquities Code Permit, \#8677 was required prior to the field survey.

The goals of the survey were to determine if the project would affect any previously identified archaeological sites as defined by the State Antiquities Code Criteria for Evaluating Archaeological Sites, and their eligibility for State Antiquities Landmark Status (TAC Title 13, Part 2, Chapter 26), and to establish if previously unidentified buried archaeological resources were located within the project's APE. All fieldwork and reporting activities were completed according to state (the Antiquities Code of Texas) and federal (NHPA) guidelines.

\subsection{Project Overview}

The project's purpose is to increase the capacity of the pipeline. To accomplish this, the existing 12 , 14, and 16-inch pipe diameters will be replaced with 16 and 20 -inch diameter pipes. Old pipes will be capped and placed in inactive service. The permitted portions of the project are located in Midland and Mitchell Counties (Figure 1-1) and are associated with two separate local governmental entities.

The City of Midland owns two parcels (tracts 6984-MD-45 and 6984-MD-46), located adjacent to each other approximately 4.8 kilometers (3 miles) southeast of Interstate 20, east of S County Road 1150 and north of $E$ County Road 120 on the Southeast Midland and Stephenson Lakes, Texas, United States Geological Service (USGS) Quadrangle Maps (Figure 1-2). One of these tracts, 6984-MD-45, includes a portion of Midland Draw, which crosses through the southern half of the parcel. The City of Colorado City owns three noncontiguous tracts (6926-MI-248A, 6926-MI249A, and 6926-MI-256A), located in proximity to Colorado City on the Colorado City, Baumann School, and Loraine, Texas, USGS Quadrangle Maps (Figures 1-3 and 14). The nearest of these, 6926-MI-256A is located approximately 3.2 kilometers (2 miles) south of the city, bounded by County Roads 105 to the west and 109 to the east. Tracts 6926MI-248A, 6926-MI-249A are located nearly 9.7 kilometers (6 miles) to the southeast of Colorado City. Both are located east of $S$ County Road 412 and south of County Road 406.

The project survey corridor within these tracts is approximately 30 meters (100 feet) wide, nearly the entirety of which consists of existing pipeline corridor. This amounts to approximately 20 hectares (50 acres) of survey corridor, which is also considered the Area of Potential Effects (APE) for the project. 


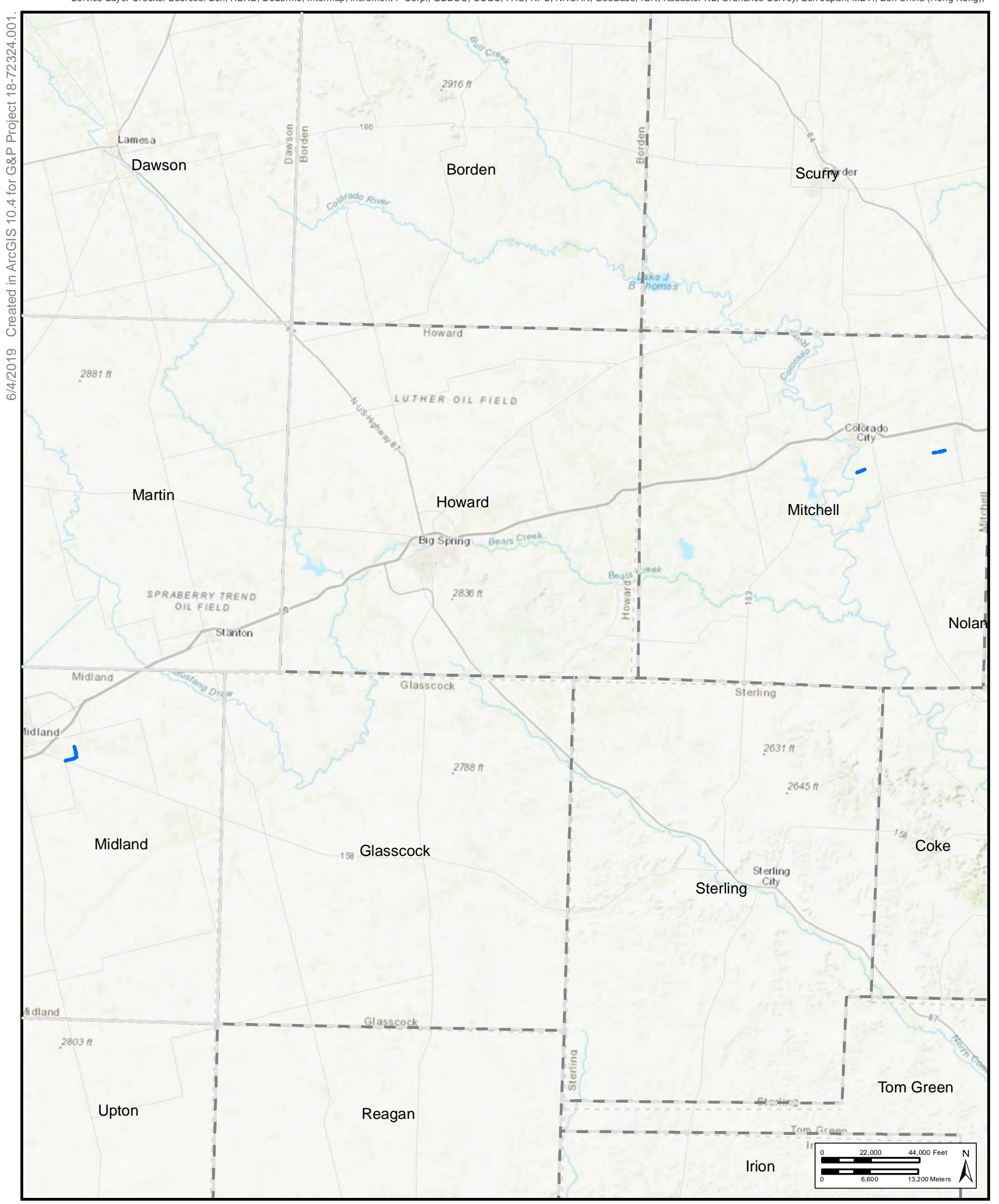

Figure 1-1

Permit area locations in Midland and Mitchell Counties, Texas.

- Permit Locations

ICounty Boundaries

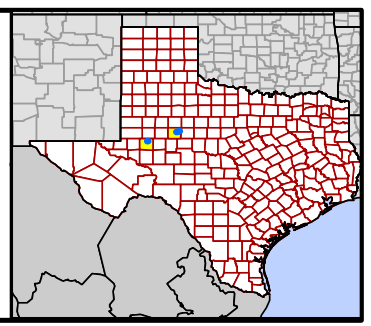




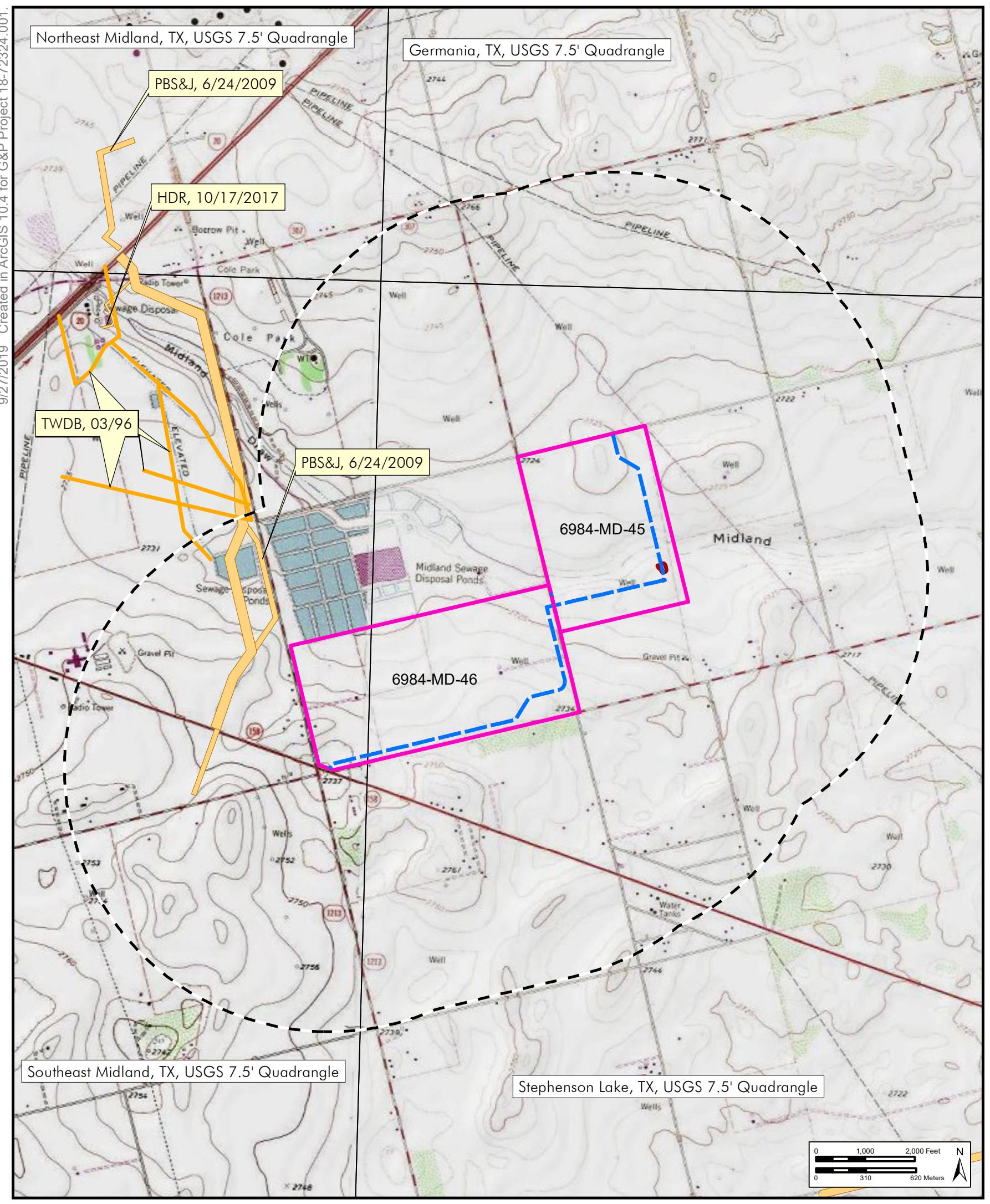

Figure 1-2

Portions of project centerline located on City of Mildand property in Midland County, Texas.

GRAY $\&$ PAPE
- - Project Centerline

$\square$ City of Midland Parcels

- Previously Recorded Linear Survey

$\square$ Previously Recorded Area Survey

$\square$ USGS Quadrangle Boundary 


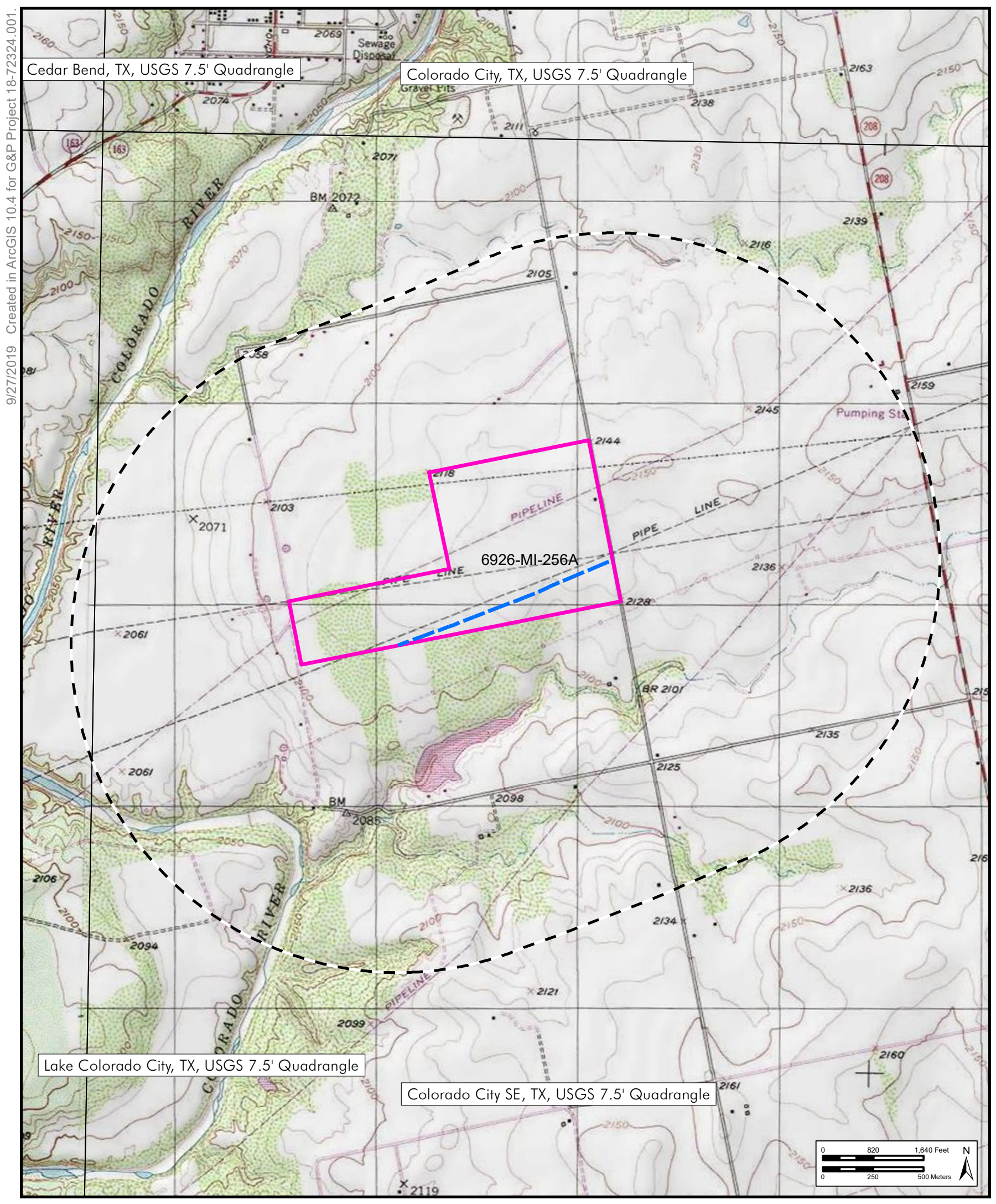

Figure 1-3

Portions of project centerline located on City of Colorado City property in Mitchell County, Texas.

GRAY \& PAPE

- - Project Centerline

$\square$ City of Colorado City Parcels $\square$ USGS Quadrangle Boundary

HERITAGE MANAGEMENT 


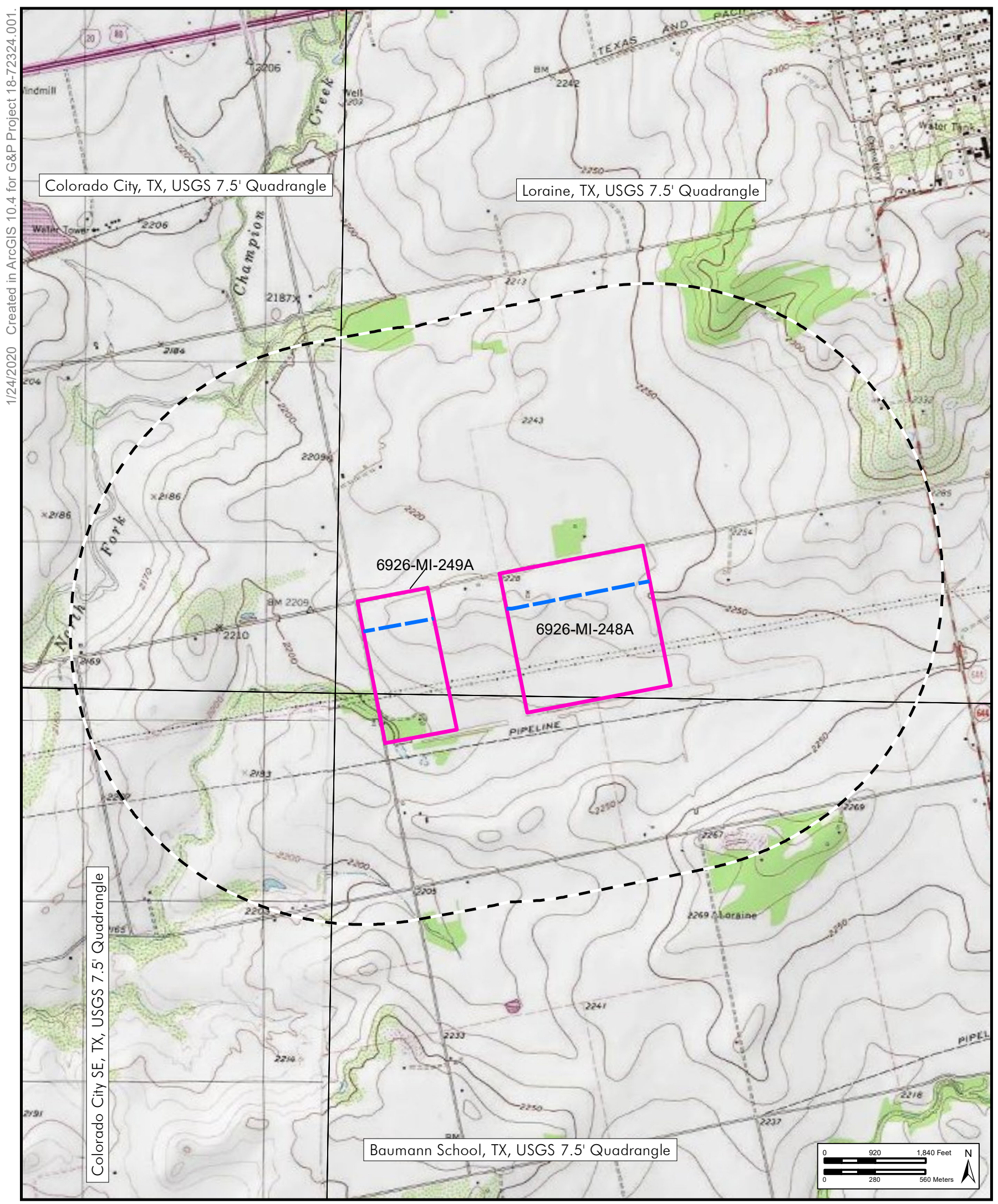

Figure 1-4

Portions of project centerline located on City of Colorado City property in Mitchell County, Texas.

GRAY \& PAPE
- Project Centerline

$\square$ City of Colorado City Parcels

- Previously Recorded Linear Survey

$\square$ Previously Recorded Area Survey $\square$ USGS Quadrangle Boundary

HERITAGE MANAGEMENT 


\subsection{Report Organization}

This report is organized into seven numbered chapters and one lettered appendix. Chapter 1.0 provides an overview of the project. Chapter 2.0 presents an overview of the environmental setting and geomorphology. Chapter 3.0 presents a discussion of the cultural context associated with the APE. Chapter 4.0 presents the research design and methods developed for this investigation. The results of this investigation are presented in Chapter 5.0. Chapter 6.0 presents the investigation summary and provides recommendations based on the results of field survey. A list of literary references cited in the body of the report is provided in
Chapter 7.0. Maps of the field survey results for each project segment are displayed in Appendix A.

\subsection{Acknowledgements}

Fieldwork was conducted January 16 and 17 , 2019, and March 5, 2019 and required 156person field hours to complete. The project was managed by Senior Principal Investigator Tony Scott. Field activities were conducted by Archaeologists Jacob Hilton and Marcia Vehling, and Field Technician Robert Beckwith. The report and graphics were prepared by Tony Scott. Jessica Bludau edited and produced the report. 


\subsection{ENVIRONMENTAL CONTEXT}

\subsection{Physiography and Geomorphology}

The project is situated in the Southern High Plains and North Central Plains areas of the Interior Plains physiographic region. The Southern High Plains, which includes Midland and the surrounding counties, are characterized by a nearly level to low rolling topography situated on an elevated plateau. This area includes portions of the Llano Estacado, a large, flat mesa that covers parts of New Mexico and northwest Texas. The areas as a whole is dotted with playa lakes formed as a result of deflation and karstic processes and served as a valuable water source for both wildlife and humans (Ferring 2007). The paleogeographic setting was a deep ocean basin surrounded by shallow carbonate platforms (Bureau of Economic Geology [BEG] 1996). Portions of the project in Mitchell County are also characterized by the rolling plains of the North Central Plains Physiographic region. The rolling terrain was created by the effects of erosion from ancient streams, leaving a landscape that is also steeply sloped in areas of highly dissected riverine edges (BEG 1996).

\subsection{Surface Geology}

The permitted portions of project cross 3 geologic formations (Table 2-1). The City of Midlandportions of the project overlay the Blackwater Draw Formation, consisting primarily of unconsolidated coarse sands and quartz above calcareous silt and clay. The Colorado City portions of the project overlay the Dockum Group Formation, consisting primarily of a sandy surface horizon underlain by shale, mudstone, and limestone. Where overlying sands have been eroded away, the underlying deposits of silt, gravel, shale, and limestone are exposed (Barnes 1967, 1977, 1983; Ferring 2007).

\subsection{Soils}

The project intersects approximately 11 soils, the majority of which are located in the Midland County Portion of the Project (Table 2-2). Nearly all of these consist of shallow (25 centimeters [10 inches] or less) surface layers of sand or sandy loam followed by thick layers of sandy clay loam, or in a few cases cemented caliche or sandstone (Soil Survey Staff, Natural Resources Conservation Service, United States Department of Agriculture [SSS NRCS USDA] 2019).

Table 2-1. Geologic Groups/Formations Intersected by the Project.

\begin{tabular}{|c|l|l|l|l|}
\hline Label & \multicolumn{1}{|c|}{ Formation/Group } & \multicolumn{1}{c|}{ Age } & \multicolumn{1}{c|}{ Rock Type 1 } & \multicolumn{1}{c|}{ Rock Type 2 } \\
\hline Qbd & Blackwater Draw & Pleistocene & sand & silt \\
\hline Qs & Sand sheet deposits & Holocene & sand & silt \\
\hline TRd & Dockum Group, undivided & Late Triassic & $\begin{array}{l}\text { fine-grained } \\
\text { mixed clastic }\end{array}$ & limestone \\
\hline
\end{tabular}

Table 2-2. Soils within the Project Area.

\begin{tabular}{|c|c|}
\hline Soil Symbol & Soil Name \\
\hline Aca & Acuff Loam, 0 To 1 Percent Slopes (Bukreek) \\
\hline Afa & Amarillo Fine Sandy Loam, 0 To 1 Percent Slopes \\
\hline Afb & Amarillo Fine Sandy Loam, 1 To 3 Percent Slopes \\
\hline
\end{tabular}




\begin{tabular}{|c|c|}
\hline Soil Symbol & Soil Name \\
\hline Bc & Bippus Clay Loam \\
\hline Bf & Brownfield Fine Sand (Heatly) \\
\hline Cmb & Cobb And Miles Fine Sandy Loams, 1 To 3\% Slopes \\
\hline Mda & Midessa Fine Sandy Loam, 0 To 1 Percent Slopes \\
\hline Mdb & Midessa Fine Sandy Loam, 1 To 3 Percent Slopes \\
\hline Mmb /Mob & Miles Loamy Fine Sand, 0 To 3 Percent Slopes \\
\hline Sab & Spade Fine Sandy Loam, 1 To 3 Percent Slopes \\
\hline Snb & Springer Fine Sandy Loam, 1 To 3 Percent Slopes \\
\hline
\end{tabular}

\subsection{Natural Environment and} Land Use

The natural vegetation in the vicinity of the project areas is largely dominated by Harvard Shin Oak and Mesquite brush and grassland (BEG 2000). However, within the survey corridor, this has nearly been entirely replaced with agricultural crops or workspaces for the oil and gas industry (BEG 2000). Wildlife include the critically endangered lesser prairie chicken, as well as mammal species such as the mule deer, bobcat, coyote, and peccary (Griffith et al. 2007).

\subsubsection{Climate}

The project area has a semi-arid climate. Rainfall is typically less than 33 centimeters (13 inches), most of which falls during spring and early summer storms. The level landscape and high intensity rains can lead to flash flooding. Summer temperatures can be intense, but a large diurnal range and low humidity results in relatively cool evenings, even in the hottest times of the year. Winter are highly variable, with cold fronts, and occasional light snows, quickly followed by rapid warming. Dust storms are also common in late winter and early spring, and dust can hang in the air for days, leading to hazy skies (Watson 1978). 


\subsection{CULTURAL CONTEXT}

\subsection{Prehistoric Context}

Prehistoric sites in the Southern High Plains and Central Plains regions are commonly found on the surface and in mixed context (Meltzer 1987). Sites are typically located along the remnants of draws, playas, and larger salina basins that have been filled in by eolian processes (Johnson and Holliday 2004). The majority of known prehistoric Clovis, Folsom, and Late Paleoindian archaeological sites in Texas are found in portions of the High Plains region near New Mexico and western Oklahoma. The general area was near the southernmost reach of now extinct megafauna in the United States and included mammoth and a large form of bison, which were frequently hunted by prehistoric groups.

Sites with historic components in the region date as far back to the 1700s as was recorded in Blanco Canyon. Most historic sites in the area represent materials left behind by Hispanic sheepherders called pastores, European buffalo hunters, military outfits, and Anglo dumpsites (Perttula 2004).

Archaeological materials that have contributed to the development of a five-period cultural chronology, as developed by Kelley (1964) and Prikryl (1990) in the area based on excavations at a handful of intact sites. For the purpose of this report an attempt is made to generalize these periods in the following paragraphs; however, it should be noted that cultural periods are not equally represented across the varying ecological and physiographic areas that the project intersects.

\subsection{Paleoindian Period}

The Paleoindian period falls within the latter part of the Pleistocene and into the early Holocene. It is generally agreed to have begun as far back as 11,500 years before present (B.P.) and continued until 8,500 B.P. and is marked by ubiquitous hunting and on-site butchering of megafauna in small nomadic groups.

The Paleoindian period is further subdivided into three more specific periods marked by projectile point technologies (Frison 1991; Holliday 1997; Wheat 1972; Wormington 1957). These include the well-known Clovis, Folsom, and Late Paleoindian periods. The Clovis period is thought to have endured at least 500 years during the latter part of the Pleistocene and its lithic technology is the oldest known in North America. Clovis points are lanceolate-shaped with short flutes (Turner and Hester 1993). Clovis points are large, heavy, and well-made tools that were used for puncturing the thick flesh of large game. The Folsom period, from 10,800-10,300 B.P., is also defined by a large fluted lanceolateshaped point. Folsom points look similar to the Clovis point, but are thinner, more symmetrical, evenly chipped on the edges, and have a single classic flute all the way up the center of the point (Turner and Hester 1993). The Late Paleoindian period, from $10,000-8,500$ B.P, is characterized by excellent craftsmanship of long, thin, narrow, lanceolate points without flutes. Instead, these points have parallel flakes and are ground with thinned bases typically accomplished with a few vertical flakes (Turner and Hester 1993). Paleoindian sites of note located in the Southern High Plains and Central Plains regions include the Lone Wolf Creek (41MH23), Midland (41MD1), and McClean (41TA29) sites.

\subsection{Archaic Period}

Following a transition to a warmer climate, the Archaic period is accepted to have lasted between 8,500-1,250 B.P. The Archaic period is marked by an adaptation to less abundant water resources and to more dependence on vegetation as a food source than compared to people living in the Paleoindian period 
(Johnson and Holliday 2004). The Archaic period is further subdivided into two periods, known as the Early and Late Archaic periods, which the former is characterized by a lack of occupational sites in the area during a time called the Altithermal when the land was hot, dry, and dusty. The Late Archaic is defined by a sudden increase in the number of sites around 4,500 B.P., when a noticeably milder climate with less hostile conditions returned to the area (Antevs 1954; Hughes 1991). Archaic sites are commonly associated with fewer megafauna kill sites than earlier Paleoindian sites. Such sites are often associated with an array of stemmed and later barbed dart points, ground stones, and hearths lined with burned stone and caliche-cobbles (Hofman 1989).

\subsection{Late Prehistoric Period}

The Archaic period was followed by the development of ceramic technology and the bow and arrow. These two inventions made way for significant sociocultural changes including a shift toward sedentism and decreased mobility. These developments are the hallmarks of the Late Prehistoric period, which lasted from A.D. 200-1450.

Because of more specific diagnostic traits associated with the Late Prehistoric, it is further subdivided into the Woodland period (A.D. 200-1450), the Palo Duro Complex (A.D. 5001100), and the Antelope Creek Phase (A.D. 1200-1450). The Lake Creek Site in the Texas Panhandle represents the Woodland Period in the High Plains, which is characterized by cordmarked ceramics, corner-notched Scallorn arrow points, and a large assemblage of lithic flake tools (Hughes 1962). Palo Duro Complex Sites are defined by the use of pit houses and evidence of plant food procurement and processing. The first evidence of such was gathered during excavations by Willey and Hughes (1978) of the Deadman's Terrace Site, more commonly called Deadman's Shelter.

Finally, the Antelope Creek Phase, sometimes called the Antelope Creek Focus is the most distinctive and well-known of the Late Prehistoric periods in the Panhandle. Hughes (1991:31) documents the highest density of Antelope Creek Sites occurring along the Canadian breaks. Antelope Creek sites are best known by their pueblo-like structures with numerous rooms. These sites are also commonly identified by the presence of bone tools, made from butchered bison, scrapers, grinding slabs for plant processing, and sometimes obsidian (Hughes 1991).

\subsection{Protohistoric Period}

The Protohistoric period dates from A.D. 1450 to AD 1600. It is defined by documented trade activities with neighboring Pueblos, increased ceramic production projectile points that seem to be confined to one of two subdivisions of the Protohistoric. The Tierra-Blanca Complex and the Garza Complex are contemporary. The Tierra-Blanca Sites are thought to have traded with the New Mexico Pueblos and are typically identified by the presence of larger villages (Hughes 1991). The Garza Complex is associated with the Garza point type which seems to only appear at Garza Complex sites. Other point types found at Garza Complex sites include the Washita, Harrell, Lott, and Fresno (Hughes 1991).

\subsection{Historic Period}

Several Native American tribes are known to have inhabited the area prior to Spanish contact in 1541; these include the Apache, Comanche, Kiowa, and Kiowa-Apache (Newcomb 1961). In the nineteenth century, the area was inhabited by the Kiowa and Comanche tribes, who preferred free range over Oklahoma's reservations (Whitlock 1970). By then, the Comanche had displaced the Apache. It is widely known that by the nineteenth century, aboriginal groups remaining in the High Plains had begun exploiting horses for use during hunting and raiding. During that time, the Comanche were assigned by the Army to reservation life in Oklahoma (Newcomb 1961). 


\subsection{Historical Context of the Region}

The earliest written descriptions of the northcentral region of Texas come as a result of Spanish exploration of the areas to the north and west of the current project. The cliff on the north facing side of the Canadian River was seen by Francisco Vásquez de Coronado in 1541 on his way east from Cíbola, leading him to name the plateau the Llano Estacado, or Palisaded Plain. In addition to recording the initial explorations of the Llano Estacado, Coronado developed the region's orientation toward the Hispanic Southwest. Coronado's efforts were mimicked by Juan de Oñate during an early seventeenth century expedition along the Canadian River. In 1872, the Llano Estacado was described by General Randolph Marcy as a "great North American desert" with "not a tree, bush or water" (Whitlock 1970).

At the time, buffalo herds were common across the Llano Estacado. In the 1870s, conflict between American buffalo hunters and regional Native-American tribes reached its apex in the Red River War. Military defeat and the slaughter of the buffalo herds forced the Comanches, Kiowa, Cheyenne, and Arapaho off the plains to reservations (Haley 2010).

The area was originally organized as Tom Green County in 1874. The massive area would eventually be subdivided into 66 modern counties (Henderson 2010). White settlement in the region remained sparse, with large cattle ranches being the primary industry. Irrigation diverted from the Pecos allowed for agriculture in some areas, but repeated drought and floods often disrupted production. It wasn't until the 1920s and the discovery of oil that the region experienced significant growth. Subsequent booms and bust within the petroleum and natural gas industries have continued to be the major driver of development of the region into the present day (Justice and Leffler 2010; Smith 2010; Leffler 2010). 


\subsection{FIELD METHODOLOGY}

This cultural resource investigation was designed to identify and assess new and previously recorded cultural resources that may be impacted by the proposed project. Desktop assessment and modeling were performed prior to initiating field investigations to better understand cultural, environmental, and geological settings. Results of the desktop assessment were then used to develop the field methodology.

\subsection{Site File and Literature Review}

The background literature search included a review of previously conducted cultural resource surveys in the vicinity of the proposed project area, and of any historic document pertaining to the history of the area. Site file research was performed to identify all previously recorded archaeological sites within a 1.6-kilometer (1mile) study radius of the project areas and any recorded historic structures eligible for the National Register of Historic Places (NRHP) or State Antiquities Landmark (SAL) listing located adjacent to the project area. Site file research was done by reviewing records maintained by the Texas Archeological Research Laboratory in Austin, Texas, and by consulting THC.

Historical topographic maps and aerial photographs when available were reviewed to identify any historic structures, residential, and other structures that might be located close to or within the project area. Historical maps of Texas and Texas counties were also reviewed in order to better understand the history of the region and to identify any potential historic trails and important historic sites located or crossing the project area.

\subsection{Field Methods}

\subsubsection{Intensive Pedestrian Survey}

Shovel testing within each segment were generally spaced every 100 meters (328 feet). This resulted in an average of approximately 16 shovel tests per mile of project length. However, tests were also judgmentally placed at closer intervals in areas of high probability, such as near water features. Subsurface testing consisted of the excavation of 30 - by 30 centimeter (12- by 12-inch) shovel tests. Vertical control was maintained by excavating each shovel test in 10-centimeter (4-inch) levels. One wall of each shovel test was profiled, and the walls and floor of each shovel test were inspected for color or texture change potentially associated with the presence of cultural features. When possible, soils were screened through 0.64-centimeter (0.25-inch) wire mesh; soils with high clay content were hand sorted in an effort to detect cultural materials in the soil matrix. Descriptions of soil texture and color followed standard terminology and the Munsell (2005) soil color charts. All the field data were recorded on appropriate field forms. All shovel tests were backfilled after excavation and documentation. The excavated shovel tests were placed on field maps and points were taken with Global Positioning System (GPS).

\subsubsection{Site Definition}

Surface visibility along the entire project length was generally 70 percent or greater. If new cultural resources were encountered, steps were taken to visually define their extent, limits, and general character. Shovel tests were also excavated at locations of surface finds and within and outside the site visible limits. For each cultural resource identified, including structures or other resources within or immediately adjacent to the APE, photographs were taken of the general vicinity and of any visible features if present. A sketch map was 
further laboratory analysis. Non-diagnostic artifacts were photographed in the field with an appropriate scale bar and either left in place or backfilled with the associated shovel test. Locations of all positive tests were recorded with a GPS.

Each identified resource was given a temporary field site number. Site forms were submitted for each cultural site identified and state-issued trinomial site numbers were requested.

If any architectural resources had been identified, these would have been recorded on corresponding field forms. Details of form, construction, material, style, condition, and alteration would be recorded both on the forms and photographically for each structure. All documentation would be reviewed by a qualified Architectural Historian who would decide if additional information or a personal field inspection was necessary at the survey level.

\subsection{Laboratory Analysis}

\subsubsection{Artifact Analysis}

No culturally or temporally diagnostic prehistoric artifacts were observed as a result of survey. Artifacts encountered in the field were fragmentary and lacked temporally diagnostic attributes. These were not collected; thus, no lab analysis was conducted. Artifacts were instead described and classified in the field as best as possible and representative samples were photographed. Data recorded in the field for uncollected artifacts included general attributes such as form (if identifiable), material, functional classification (if identifiable), and counts.

\subsection{Curation}

No diagnostic or non-diagnostic artifacts were collected in the course of the current survey. As a project permitted through the THC; however, Gray \& Pape submitted project records to the Center of Archaeological Studies at Texas State University. 


\subsection{RESULTS OF INVESTIGATIONS}

\subsection{Result of Site File and Literature Review}

A search of the Texas Archeological Sites Atlas, maintained by the THC, determined that no National Register properties intersect the project alignment. Additionally, the same research identified that two previously recorded archaeological sites, two previously conducted archaeological surveys, no historical markers, and no cemeteries had been recorded within the 1.6-kilometer (1-mile) study radius of the project areas (Figures 1-2 to 1-4).

\subsubsection{Previously Recorded Surveys and Resources}

According to a search of the Texas Archeological Sites Atlas, only two previously recorded surveys have been conducted within a 1.6-kilometer (1-mile) study radius of the project areas. One area survey was conducted by PBS\&J in 2009 for the proposed El Camino to Midland Pipeline Project (Figures 1-2). Another was a linear survey conducted by the Texas Water Development Board in 1996. Neither previous project intersects the current project alignment. No additional previously recorded surveys or any cultural resources are recorded within 1.6 kilometers $(1$ mile) of the project areas.

Both previously recorded sites $41 \mathrm{MH} 14$ and $41 \mathrm{MH} 15$ are located west of City of Colorado City tract 6926-MI-249A (Figure 1-4). Site $41 \mathrm{MH} 14$ was recorded in 1932. The site form describes the site as an artifact scatter / midden / camp located on a sandstone hill along a stream (tributary of North Fork Champion Creek). Materials recorded consist of a biface, projectile point, knife, red pigment, and undetermined stone artifacts. No additional information was available per the site form (THC 2019).
Site $41 \mathrm{MH} 15$ appears to be a duplicate record of Site $41 \mathrm{MH} 14$, although is mapped in a different location. All the information on the site record is the same as that listed for Site $41 \mathrm{MH} 14$. No additional information was available per the site form (THC 2019).

\subsection{Results of Field Investigations}

Fieldwork was conducted over two mobilizations, the first taking place on January 16 and 17 of 2019. During that effort, the project was investigated by pedestrian survey that included surface reconnaissance and shovel testing. The project areas consisted largely of agricultural fields with surface visibility of 90 percent or more throughout (Figure 5-1), although Tract 6984-MD-46 was pasture or fallow and displayed short grasses and brush (Figure 5-2). Ongoing disturbance was present along the proposed centerline in Tract 6984MD-45 as work was being conducted on pipeline not associated with the current project (Figure 5-3).

A total of 83 shovel tests were excavated as a result of survey of current and former alignments (Figures $\mathrm{A} 1$ to $\mathrm{A} 5$ ). An additional 33 shovel tests were performed as part of site delineation for a total of 116 shovel tests excavated for the project. Due to adjustments in the project alignment, two different alignments were surveyed within Tracts 6984-MD-45 and 6926MI-248A. These former routes are labeled as such on Figures $A 1$ and $A 5$. These routes are no longer being considered for the project. Of the 83 shovel tests excavated, two were positive for cultural materials and resulted in the discovery of Site 41MD58, discussed in more detail below. 


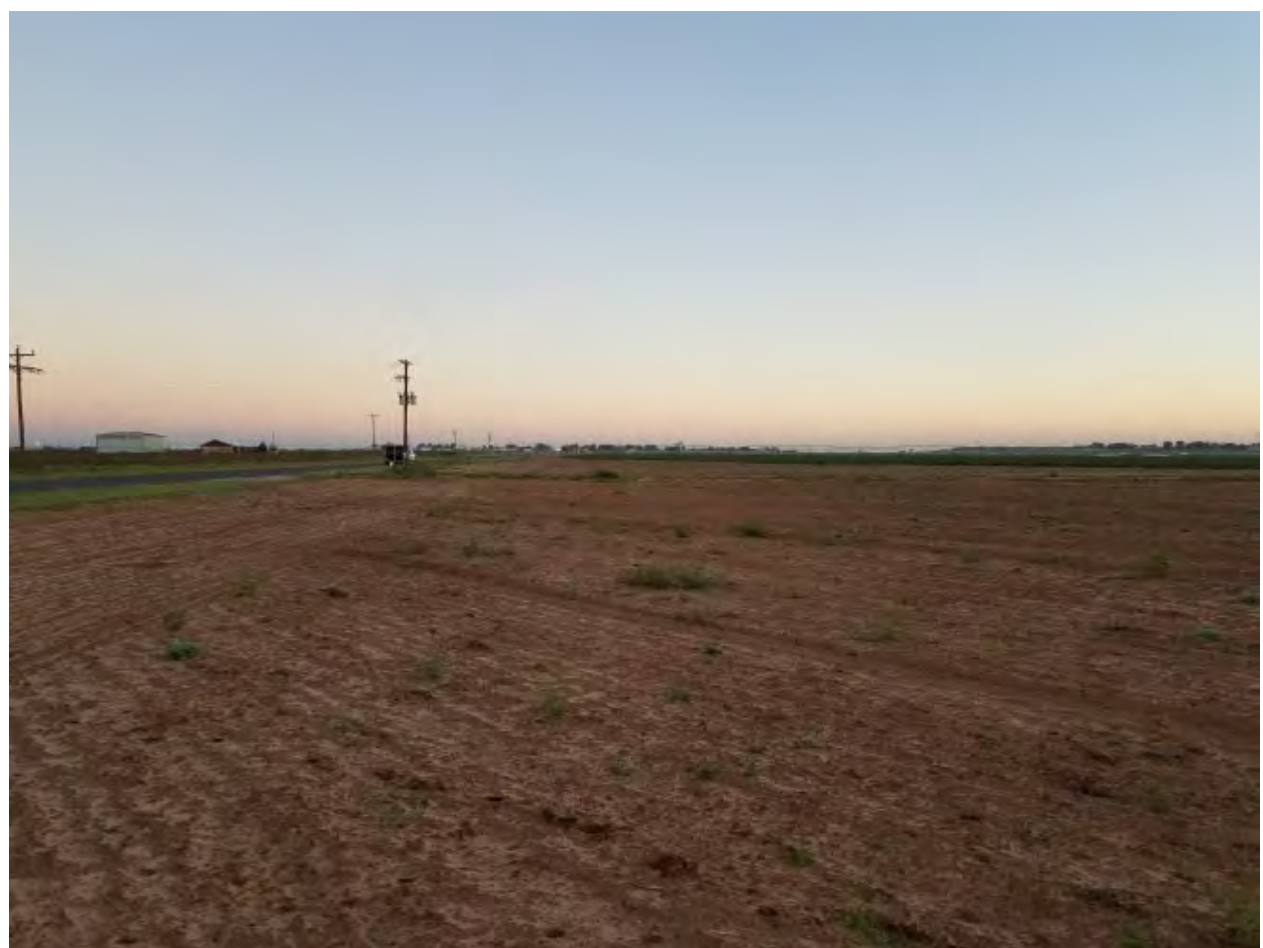

Figure 5-1. Overview of field conditions in Tract 6926-MI-248A. View is to the west.

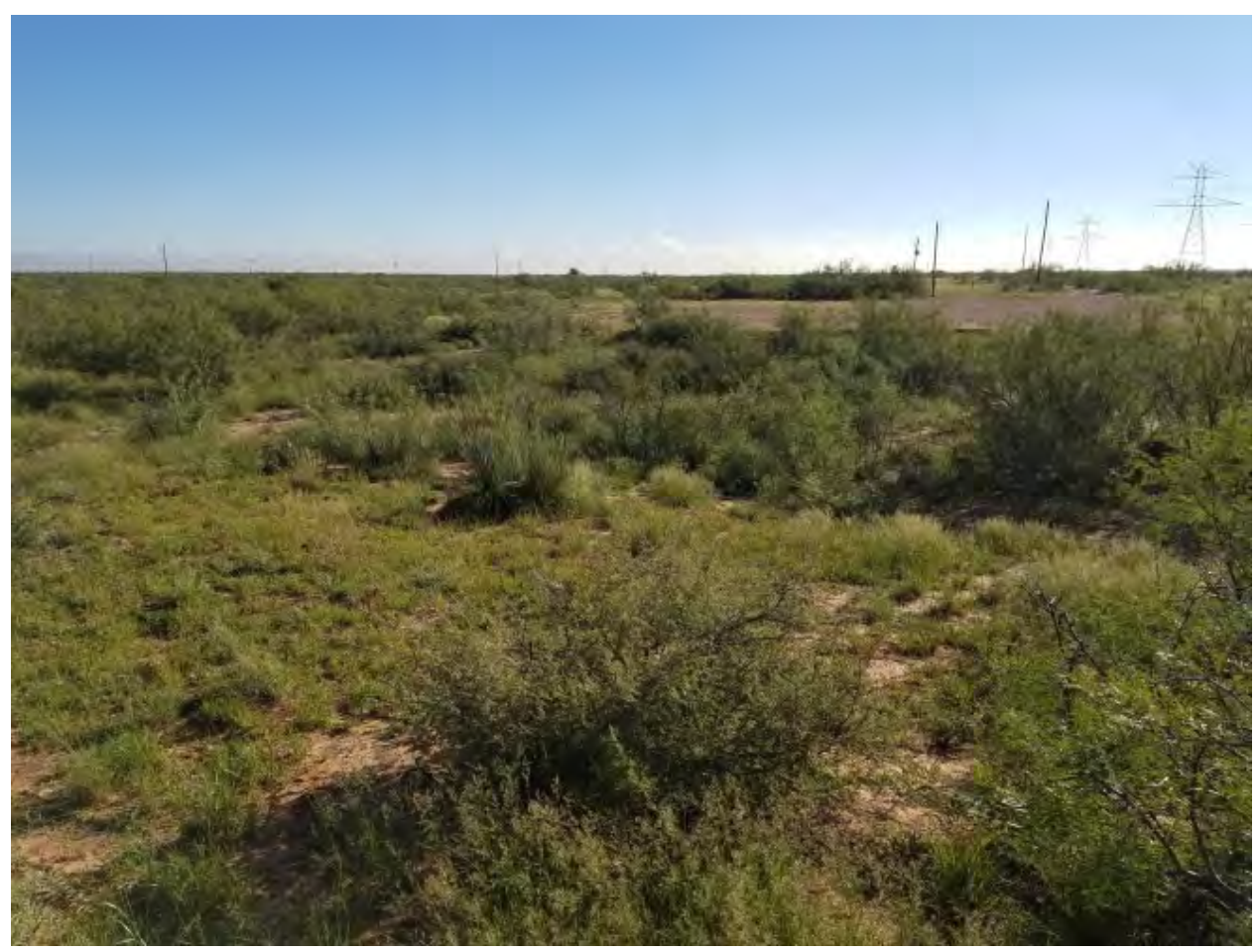

Figure 5-2. Overview of field conditions in Tract 6984-MD-46. View is to the east. 


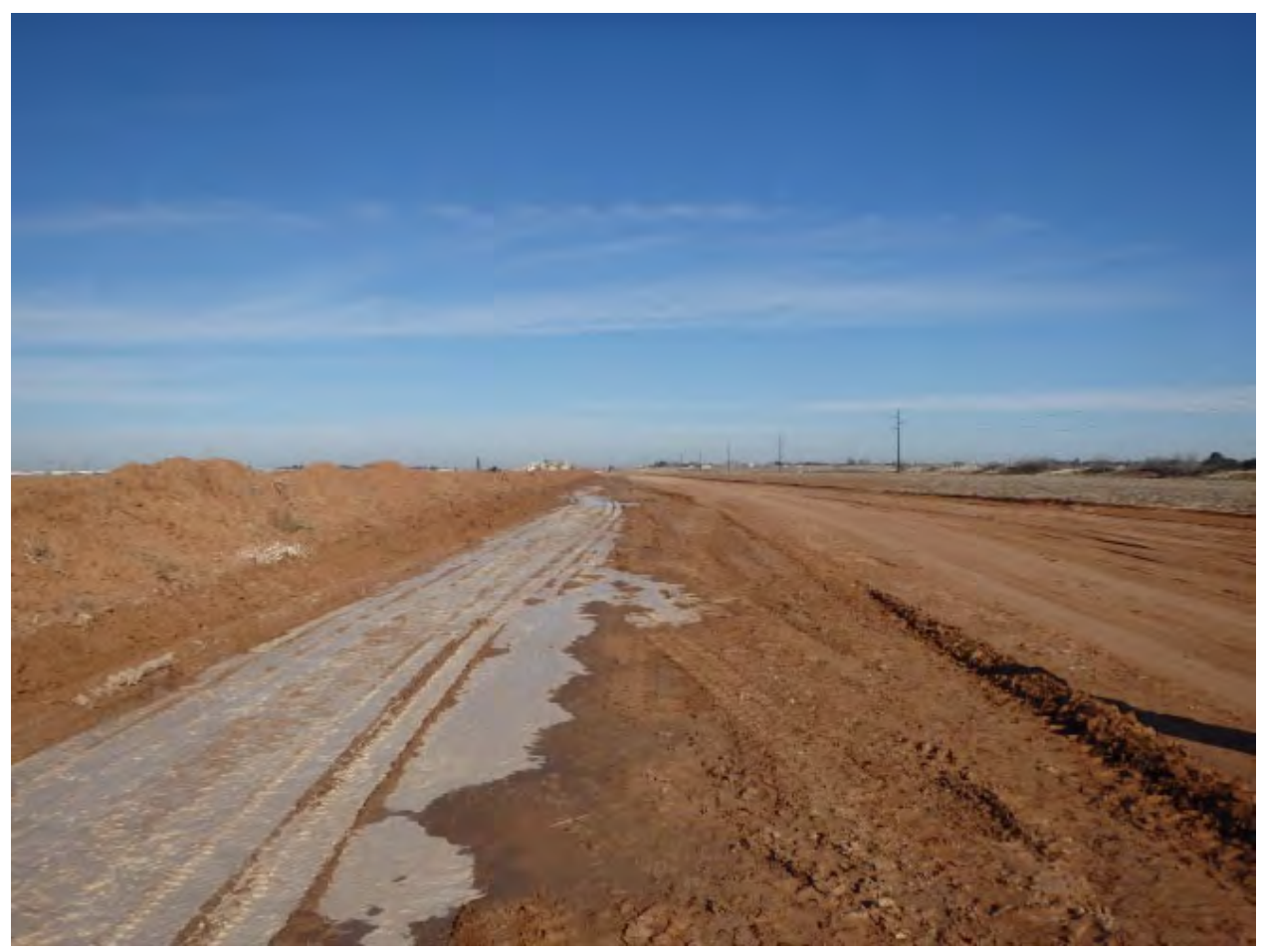

Figure 5-3. Ongoing pipeline work being conducted within the current corridor at the time of survey in Tract 6984-MD-45. View is to the north.

\subsubsection{Newly Identified Site 41MD58}

Site 41 MD58 is a prehistoric surface and buried lithic scatter, located 715 meters east of $\mathrm{S}$ County $\mathrm{Rd} 1140$, and 685 meters north of $E$ County Rd 120, 95 meters south of Midland Draw (Figure A2). The northern half of the location consists of short grasses (Figure 5-4) and the southern half lies in a fallow cotton field (Figures 5-5).

The site was recorded in the field during an initial pedestrian survey of the property on January 16, 2019. Survey resulted in the two positive shovel tests, A1 and ST-1 (Figure 5-6). Each test contained a single chert flake within 20 to 30 centimeters ( 8 to 12 inches) below the surface (Tables 5-1 and 5-2). Two surface finds were also identified during pedestrian survey in association with these tests. The finds consisted of a chert biface located near test ST-1 (Figure 5-7) and a flake observed near test $A 1$.
Delineation of these finds was conducted on March 5, 2019 and resulted in the excavation of an additional 33 shovel tests placed in cardinal directions spaced 10 meters (33 feet) apart located within and outside of the APE (Figure 5-6). Of those 33 tests, eight were positive for additional cultural materials. These consisted of chert flakes and fire-cracked rock (FCR) (Tables 5-1 and 5-2). Two additional surface finds of possible FCR fragments were also observed during the delineation. Except for one quartz flake, all lithic artifacts were composed of butterscotch colored chert and FCR appeared to be of limestone (Figure 5-8).

The resultant site boundary measures 100 meters (330 feet) north to south and 50 meters (165 feet) wide at its widest point. Soil mapped for the area consists of Springer fine sandy loam, 1 to 3 percent slopes. This is a very deep, well-drained sandy soil, formed in eolian sediments and alluvium. It is typically located on stream terraces of alluvial plains and contains a 
typical profile of six strata (A-Bt1-B+2-Eb-Btb$\mathrm{Bcb}$ ) to a depth of 213 centimeters (84 inches). Soil profiles generally consist of a surface (A horizon) light brown (7.5YR 6/4) loamy fine sand to a depth of 41 centimeters (16 inches). That is followed by two successive subsoil layers ( $\mathrm{B}+1-\mathrm{B}+2$ horizons) of reddish brown (5YR 5/4) to yellowish red (5YR 5/6) fine sandy loam to a depth of 107 centimeters (42 inches). Below that is a subsoil (E horizon) reddish yellow (5YR 6/6) loamy fine sand to a depth of 142 centimeters (56 inches). This is followed by consecutive subsoil strata ( $\mathrm{B}+\mathrm{b}-\mathrm{BC}$ ) of yellowish red (5YR 5/6) and reddish yellow (5YR 6/6) fine sandy loam to a depth of 213 centimeters (84 inches) (NRCS 2019).

A representative soil profile for the site consists of strong brown (7.5YR 5/6) to yellowish brown (10YR 5/6) fine sand to depths of between 20 and 80 centimeters ( 8 and 31.5 inches). This was followed by a second stratum of reddish brown (5YR 5/4) to yellowish red (5YR 5/6) medium to coarse granular fine sandy loam to 1 meter (39 inches) (Table 5-1). This profile appears to be consistent with the Springer soil series mapped for the location. Subsoils were reached in nearly all tests and the potential for deeply buried materials is considered low.
While the site contains soil deposition, the majority of the location has encountered either pipeline or agricultural related previous impacts. Even at the time of site delineation, work on an adjacent pipeline was taking place, limiting the extent of the delineation work in the southern portion of the site (Figure 5-9). Although examples of FCR were observed at the site, the fine sands which comprise the location do not appear to have retained any discernable occupation zones or features. Rather, the cultural materials were observed at varied depths. This finding along with the fine sandy composure of the soil suggests the dispersal and migration of materials through the substrate.

Within the current APE, the resource appears to have experienced moderate surface disturbance due to previous pipeline and agricultural impacts and subsurface impacts from natural and artificial processes, mainly artifact dispersal and migration through the loose sandy soils. This observation combined with the sparsity of artifacts, lack of diagnostics, and lack of features suggests the resource is not significant. 


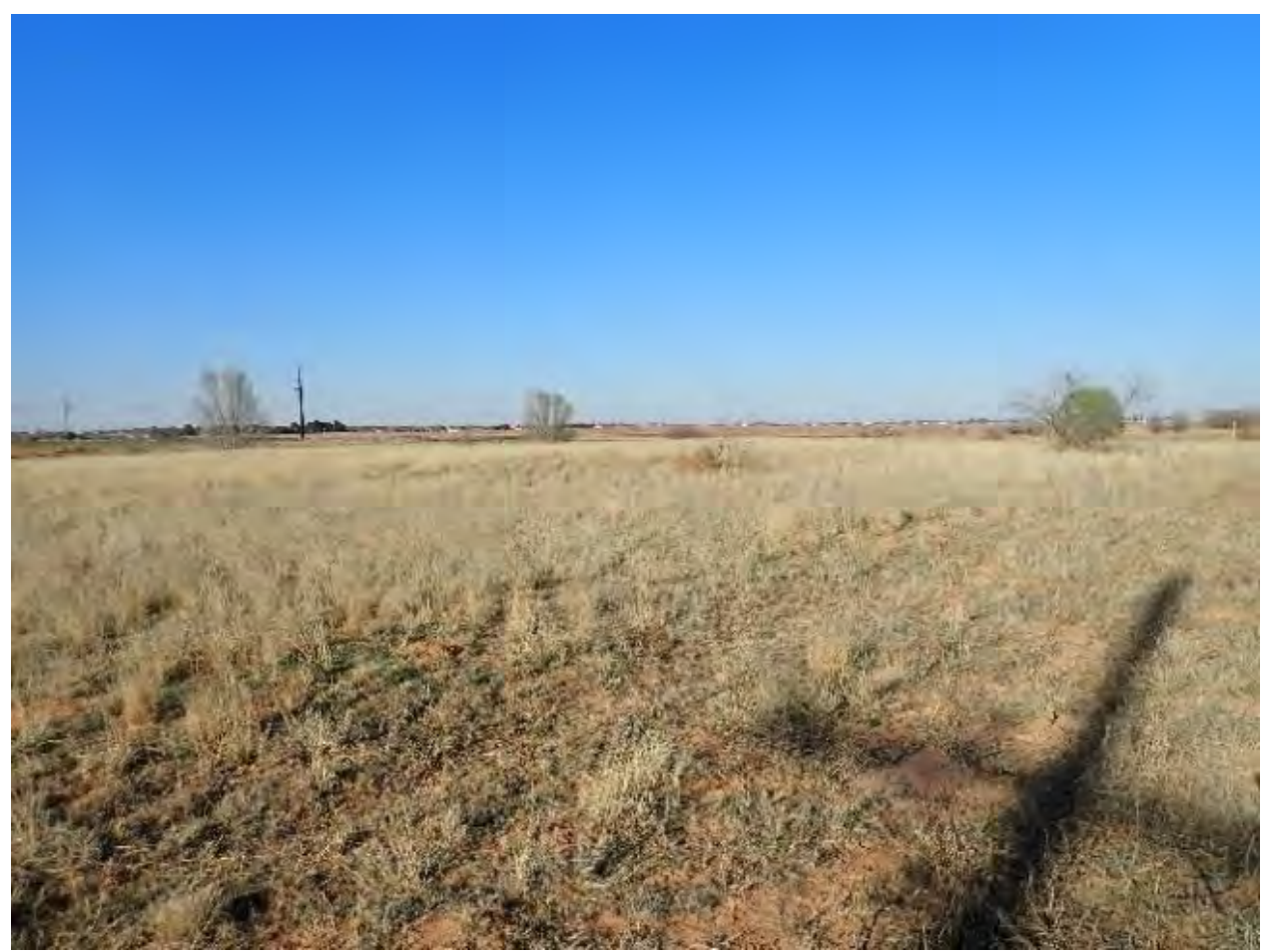

Figure 5-4. Overview of the northern half of Site 41MD58. View is to the northeast.

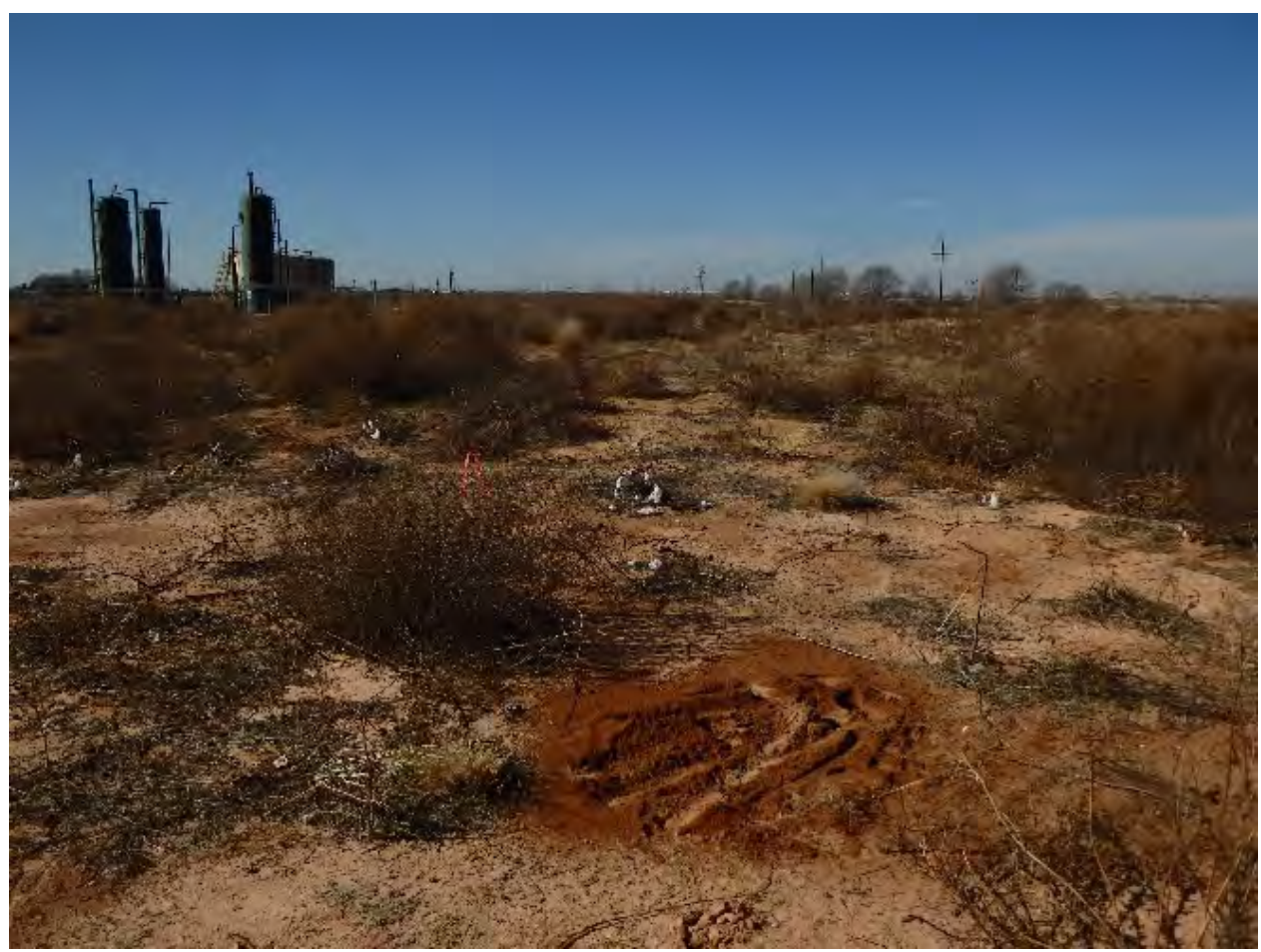

Figure 5-5. Overview of the southern half of Site 41MD58. View is to the southwest. 
REMOVED FROM PUBLIC COPY

Plan map of Site 41 MD58. 
Table 5-1. Provenience of Subsurface Materials Identified within Site 41MD58.

\begin{tabular}{|c|c|c|c|c|c|c|c|c|}
\hline $\begin{array}{c}\text { Test } \\
\text { Number }\end{array}$ & $\begin{array}{l}\text { Strat I } \\
\text { Depth }\end{array}$ & $\begin{array}{c}\text { Strat I } \\
\text { Munsell }\end{array}$ & $\begin{array}{l}\text { Strat I } \\
\text { Texture }\end{array}$ & $\begin{array}{c}\text { Strat I Field } \\
\text { Sample }\end{array}$ & $\begin{array}{l}\text { Strat II } \\
\text { Depth }\end{array}$ & $\begin{array}{c}\text { Strat II } \\
\text { Munsell }\end{array}$ & $\begin{array}{l}\text { Strat II } \\
\text { Texture }\end{array}$ & $\begin{array}{c}\text { Strat II Field } \\
\text { Sample }\end{array}$ \\
\hline $\mathrm{A} 1$ & $60 \mathrm{cmbs}$ & 10YR 5/6 & $\begin{array}{l}\text { Single } \\
\text { grain } \\
\text { loamy } \\
\text { fine sand }\end{array}$ & $\begin{array}{c}1 \text { flake } \\
\text { fragment at } \\
20 \mathrm{cmbs}\end{array}$ & & & & \\
\hline $\begin{array}{l}\mathrm{Al}+ \\
10 \mathrm{~N}\end{array}$ & $55 \mathrm{cmbs}$ & $\begin{array}{c}7.5 Y R \\
5 / 6\end{array}$ & $\begin{array}{l}\text { Single } \\
\text { grain fine } \\
\text { sand }\end{array}$ & & $\begin{array}{c}100 \\
\mathrm{cmbs}\end{array}$ & $\begin{array}{l}\text { 5YR 5/4 } \\
\text { mottled } \\
5 Y R 5 / 6\end{array}$ & $\begin{array}{l}\text { Medium } \\
\text { to fine } \\
\text { granular } \\
\text { fine sandy } \\
\text { clay }\end{array}$ & $\begin{array}{c}1 \text { complete } \\
\text { interior chert } \\
\text { flake } 50-60 \\
\text { cmbs }\end{array}$ \\
\hline $\begin{array}{l}\mathrm{Al}+ \\
20 \mathrm{~W}\end{array}$ & $80 \mathrm{cmbs}$ & $\begin{array}{c}7.5 Y R \\
5 / 6\end{array}$ & $\begin{array}{l}\text { Single } \\
\text { grain } \\
\text { loamy } \\
\text { fine sand }\end{array}$ & $\begin{array}{c}1 \text { interior } \\
\text { chert flake } \\
\text { fragment on } \\
\text { surface }\end{array}$ & $\begin{array}{l}100 \\
\mathrm{cmbs}\end{array}$ & 5YR 5/6 & $\begin{array}{l}\text { Medium } \\
\text { to coarse } \\
\text { granular } \\
\text { fine sandy } \\
\text { loam }\end{array}$ & \\
\hline $\begin{array}{l}\mathrm{Al}+ \\
10 \mathrm{~W}\end{array}$ & $27 \mathrm{cmbs}$ & $\begin{array}{c}7.5 Y R \\
5 / 6\end{array}$ & $\begin{array}{l}\text { Single } \\
\text { grain } \\
\text { loamy } \\
\text { fine sand }\end{array}$ & $\begin{array}{c}1 \text { Limestone } \\
\text { FCR 0-10 } \\
\text { cmbs }\end{array}$ & $99 \mathrm{cmbs}$ & 5YR 5/6 & $\begin{array}{l}\text { Medium } \\
\text { to coarse } \\
\text { granular } \\
\text { fine sandy } \\
\text { loam }\end{array}$ & $\begin{array}{l}1 \text { interior chert } \\
\text { flake } 60-70 \\
\text { cmbs }\end{array}$ \\
\hline $\begin{array}{l}\mathrm{Al}+ \\
10 \mathrm{E}+ \\
10 \mathrm{~N}\end{array}$ & $36 \mathrm{cmbs}$ & $\begin{array}{c}7.5 Y R \\
5 / 6\end{array}$ & $\begin{array}{l}\text { Single } \\
\text { grain } \\
\text { loamy } \\
\text { fine sand }\end{array}$ & & $98 \mathrm{cmbs}$ & 5YR 5/6 & $\begin{array}{l}\text { Medium } \\
\text { to coarse } \\
\text { granular } \\
\text { fine sandy } \\
\text { loam }\end{array}$ & $\begin{array}{l}1 \text { interior chert } \\
\text { flake fragment } \\
40-50 \mathrm{cmbs}\end{array}$ \\
\hline $\begin{array}{c}\mathrm{Al}+ \\
10 \mathrm{~W}+ \\
10 \mathrm{~S}\end{array}$ & $23 \mathrm{cmbs}$ & $\begin{array}{c}7.5 Y R \\
5 / 6\end{array}$ & $\begin{array}{l}\text { Single } \\
\text { grain } \\
\text { loamy } \\
\text { fine sand }\end{array}$ & & $97 \mathrm{cmbs}$ & $\begin{array}{l}\text { 5YR 5/4 } \\
\text { mottled } \\
5 Y R 5 / 6\end{array}$ & $\begin{array}{l}\text { Medium } \\
\text { to fine } \\
\text { granular } \\
\text { fine sandy } \\
\text { loam }\end{array}$ & $\begin{array}{c}3 \text { FCR at } 26 \\
\text { cmbs; } 1 \text { int } \\
\text { chert flake } 30 \text { - } \\
40 \mathrm{cmbs}\end{array}$ \\
\hline $\begin{array}{l}\mathrm{Al}+ \\
10 \mathrm{E}+ \\
10 \mathrm{~S}\end{array}$ & $29 \mathrm{cmbs}$ & $\begin{array}{c}7.5 Y R \\
5 / 6\end{array}$ & $\begin{array}{l}\text { Single } \\
\text { grain } \\
\text { loamy } \\
\text { fine sand }\end{array}$ & $\begin{array}{c}1 \text { interior } \\
\text { chert flake } \\
\text { fragment 10- } \\
20 \mathrm{cmbs}\end{array}$ & $92 \mathrm{cmbs}$ & $\begin{array}{l}\text { 5YR 5/4 } \\
\text { mottled } \\
5 Y R 5 / 6\end{array}$ & $\begin{array}{l}\text { Medium } \\
\text { to fine } \\
\text { granular } \\
\text { fine sandy } \\
\text { loam }\end{array}$ & \\
\hline $\begin{array}{l}\mathrm{Al}+ \\
20 \mathrm{E}+ \\
10 \mathrm{~S}\end{array}$ & $70 \mathrm{cmbs}$ & $\begin{array}{c}7.5 Y R \\
5 / 6\end{array}$ & $\begin{array}{l}\text { Single } \\
\text { grain } \\
\text { loamy } \\
\text { fine sand }\end{array}$ & $\begin{array}{c}1 \text { interior } \\
\text { chert flake } \\
\text { fragment } 30 \text { - } \\
40 \mathrm{cmbs}\end{array}$ & $\begin{array}{l}100 \\
\mathrm{cmbs}\end{array}$ & 5YR 5/6 & $\begin{array}{c}\text { Medium } \\
\text { to coarse } \\
\text { granular } \\
\text { fine sandy } \\
\text { loam }\end{array}$ & \\
\hline $\begin{array}{l}\mathrm{Al}+ \\
10 \mathrm{E}+ \\
30 \mathrm{~S}\end{array}$ & $19 \mathrm{cmbs}$ & $\begin{array}{c}7.5 Y R \\
5 / 6\end{array}$ & $\begin{array}{c}\text { Massive } \\
\text { loamy } \\
\text { fine sand } \\
\text { with } \\
\text { caliche } \\
\text { (disturbed } \\
\text { ) }\end{array}$ & & $\begin{array}{c}105 \\
\mathrm{cmbs}\end{array}$ & 5YR 5/4 & $\begin{array}{l}\text { Medium } \\
\text { to fine } \\
\text { granular } \\
\text { fine sandy } \\
\text { loam }\end{array}$ & $\begin{array}{c}1 \text { comp. int. } \\
\text { chert flake; } 1 \\
\text { possible FCR } \\
40-50 \mathrm{~cm} ; 1 \\
\text { broken } \\
\text { quartzite flake; } \\
1 \text { chert debris } \\
90-100 \mathrm{~cm}\end{array}$ \\
\hline ST- 1 & $80 \mathrm{cmbs}$ & 10YR 5/6 & $\begin{array}{l}\text { Single } \\
\text { grain } \\
\text { loamy } \\
\text { fine sand }\end{array}$ & $\begin{array}{c}1 \text { flake } \\
\text { fragment at } \\
30 \mathrm{cmbs}\end{array}$ & & & & \\
\hline
\end{tabular}

$\mathrm{cmbs}=$ centimeters below surface 
Table 5-2. Artifact Distribution Observed at Site 41MD58.

\begin{tabular}{|c|c|c|c|}
\hline Depth & Flakes & Bifaces & FCR \\
\hline Surface & 2 & 1 & 1 \\
\hline $0-10$ & - & - & - \\
\hline $10-20$ & 2 & - & 3 \\
\hline $20-30$ & 3 & - & - \\
\hline $30-40$ & 2 & - & 1 \\
\hline $40-50$ & 2 & - & - \\
\hline $50-60$ & 1 & - & - \\
\hline $60-70$ & 1 & - & - \\
\hline $70-80$ & - & - & - \\
\hline $80-90$ & - & - & \\
\hline $90-100$ & 2 & & \\
\hline
\end{tabular}

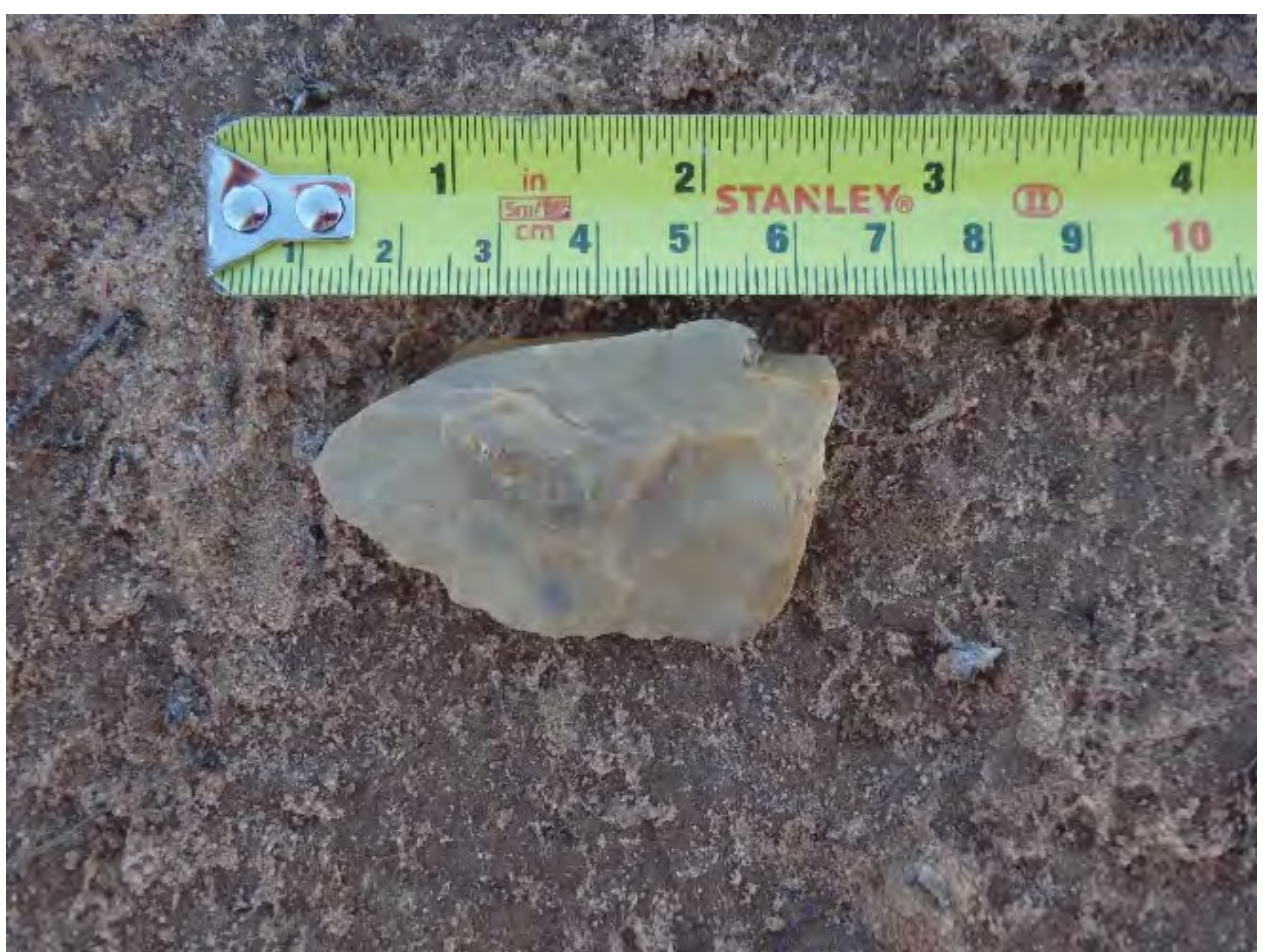

Figure 5-7. Biface recorded on the surface of Site 41MD58. 


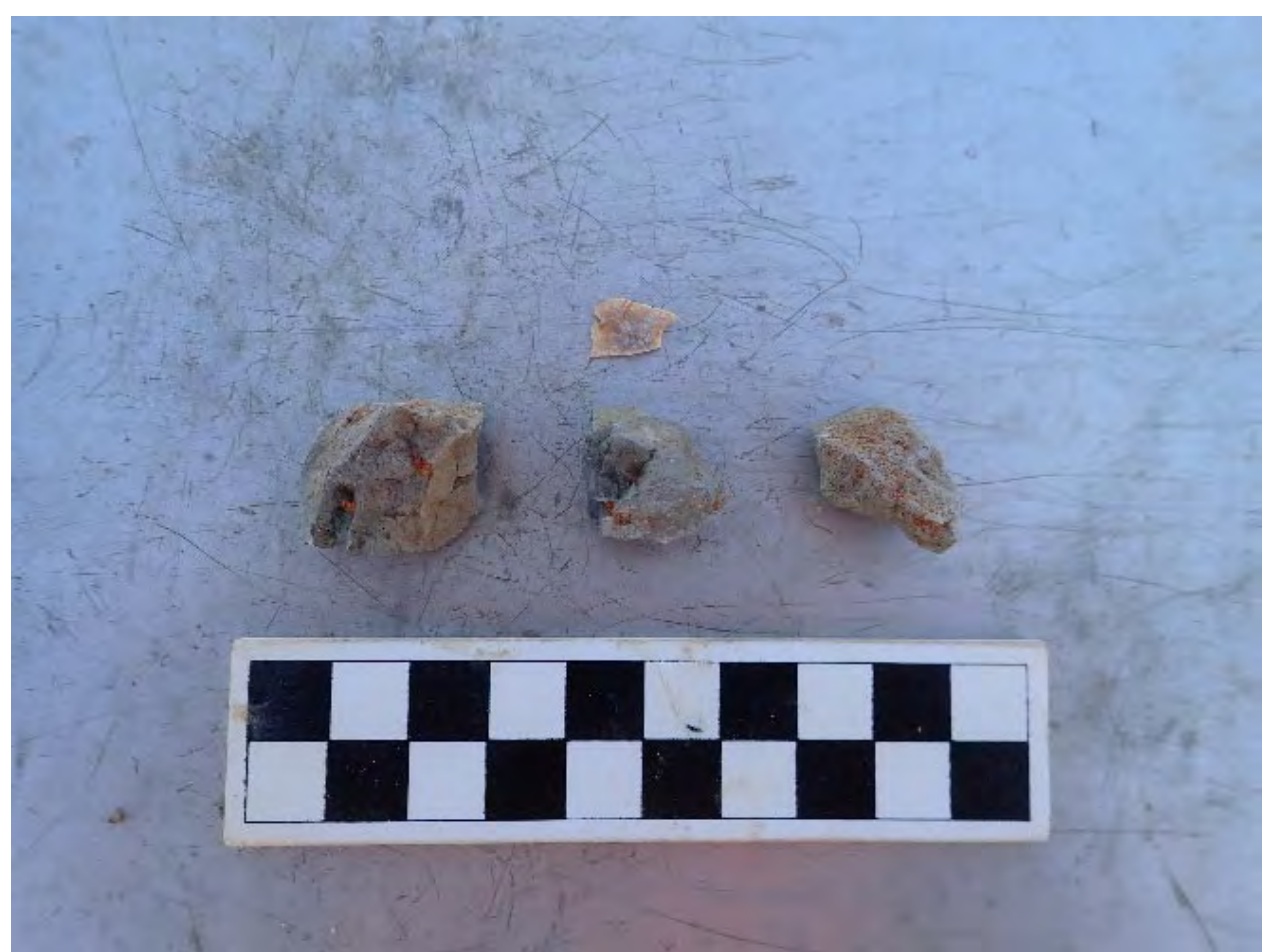

Figure 5-8. Three limestone FCR fragments and 1 chert flake observed in Shovel Test A1 + 10W + 10S.

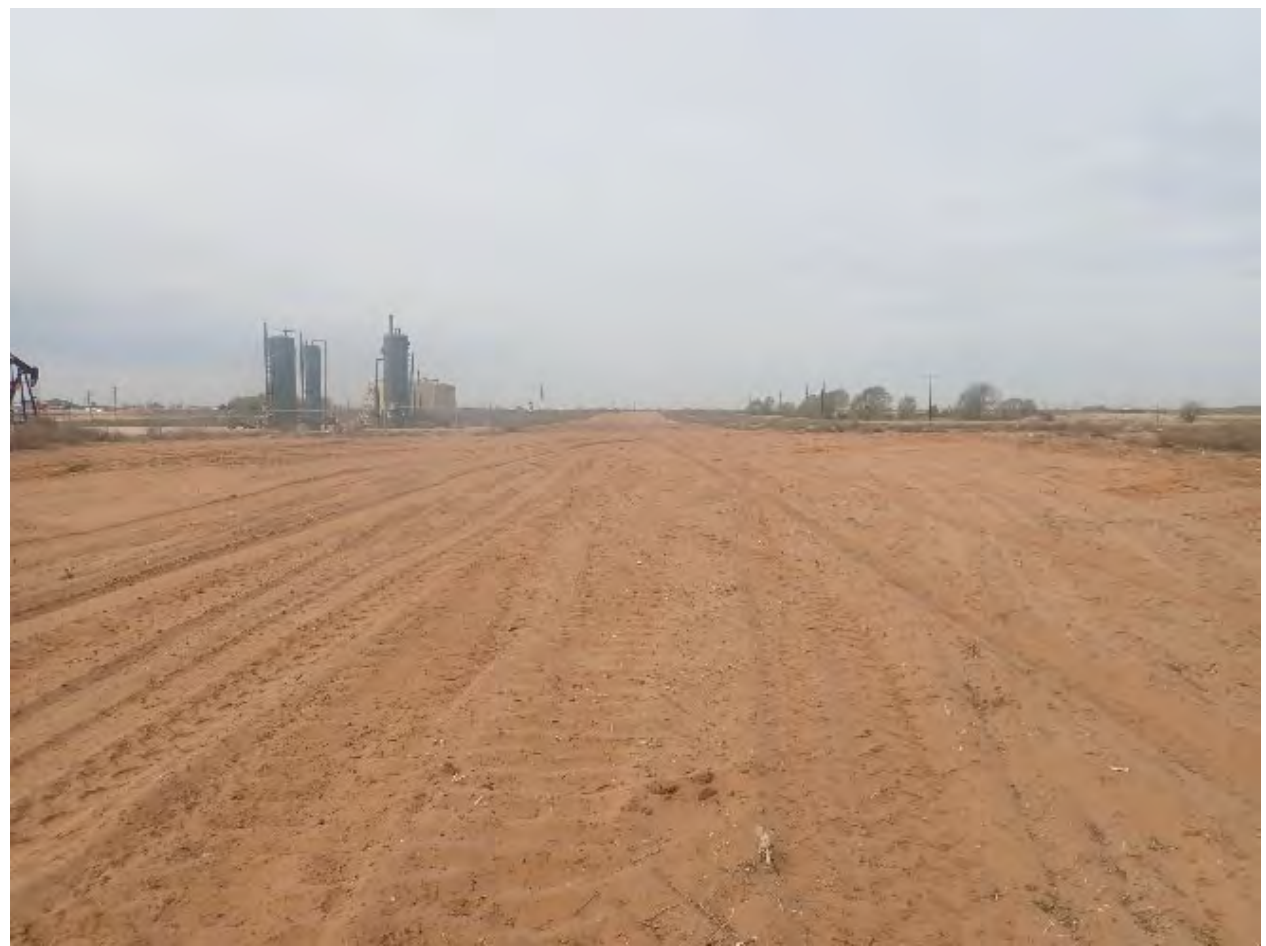

Figure 5-9. Overview of active pipeline work taking place within the southern half of Site 41MD58 at the time of delineation survey. View is to the east. 


\subsection{CONCLUSIONS AND RECOMMENDATIONS}

Gray \& Pape of Houston, Texas, was contracted by BIO-WEST to conduct an archaeological survey for the Orion Refurbishment Pipeline project on publicly owned property in Midland and Mitchell Counties, Texas. The project is designed to increase the capacity of the existing pipeline. This report details the results of survey of approximately 3.2 kilometers (2 miles) spanning five properties: two under the ownership of the City of Midland and three under the ownership of the City of Colorado City. Work undertaken on the properties will be reviewed under the Texas Antiquities Code (Texas Natural Resource Code, Title 9, Chapter 191), Permit number 8677.

A records and literature review of the project location prior to survey identified no previously recorded archaeological sites or previously conducted surveys intersect the project alignment within these properties. Fieldwork was conducted in two mobilizations in January and March 2019. The project involved archaeological reconnaissance and shovel testing throughout the entire Area of Potential Effects. Approximately 16 shovel tests were excavated for every mile surveyed with emphasis placed in areas of high probability. In total, 83 shovel tests were excavated along current and previously planned routes within the permitted properties.
Gray \& Pape identified one new archaeological site as a result of survey. Site 41MD58 consists of a low-density surface and buried lithic scatter. The presence of fragments of FCR suggest the location consisted of a small ephemeral campsite. The resource area shows clear disturbance from previous impacts associated with the pipeline right-of-way and agriculture as well as natural processes indicated by artifact dispersion. The site did not contain temporally or culturally diagnostic artifacts and no artifacts were collected. Despite the presence of FCR, there were no observable evidence of intact features present. It is the opinion of Gray \& Pape that the site has been well delineated and based on the findings offers little potential for further research. The paucity of artifacts, lack of diagnostic materials, fragmentary nature of the artifacts, and lack of integrity, suggests that the site does not have the potential to add further insight on prehistoric or historic occupation in the region. Thus, the site is recommended not eligible for listing in the NRHP according to Criteria A through D.

Gray \& Pape recommends no additional archaeological work for the portions of project corridor permitted through the Antiquities Code of Texas. 


\subsection{REFERENCES CITED}

Antevs, Ernst

1954 Climate of New Mexico During the Last Glacio-Pluvial, Journal of Geology 62.2, pp. 182191.

Barnes, Virgil

1967 Bureau of Economic Geology, Sherman Sheet, Geologic Atlas of Texas: University of Texas at Austin, Bureau of Economic Geology, scale 1:250,000.

1977 Bureau of Economic Geology, Clovis Sheet, Geologic Atlas of Texas, Bureau of Economic Geology, University of Texas at Austin, scale 1:250,000.

1983 Bureau of Economic Geology, Tucumcari Sheet, Geologic Atlas of Texas, Bureau of Economic Geology, University of Texas at Austin, scale 1:250,000.

Bureau of Economic Geology (BEG)

1996 Physiographic Map of Texas. The University of Texas at Austin.

2000 Vegetation/Cover Types of Texas. The University of Texas at Austin.

2008 General soil Map of Texas. The University of Texas at Austin.

Ferring, C. Reid

2007 The Geology of Texas. Thompson Corporation, Stamford.

Frison, G.C.

1991 The Goshen Paleoindian Complex: New Data for Paleoindian Research. In Clovis and Adaptations, edited by R. Bonnichsen and K.L. Turnmire. Center for the Study of the First Americans, University of Maine, Orono.

Griffith, Glenn, Sandy Bryce, James Omernik, and Anne Rogers

2007 Ecoregions of Texas. Dynamac Corporation, Corvallis.

Haley, James L.

2010 Red River War. Handbook of Texas Online. http://www.tshaonline.org/handbook/online/articles/qdrO2. Accessed January 1 1, 2019.

Henderson, John C.

2010 Tom Green County. Handbook of Texas Online.

https://tshaonline.org/handbook/online/articles/hct07. Accessed January 1 1, 2019.

Hofman, Jack L.

1989 Prehistoric Culture History $\neg-$ Hunters and Gatherers in the Southern Great Plains. In From Clovis to Comanchero: Archaeological Overview of the Southern Great Plains, by Jack L. Hofman, Robert L. Brooks, Joe S. Hayes, and Douglas W. Owsley, Richard L. Jantz, Murray K. Marks, and Mary H. Manheim. Research Series No. 35. Arkansas Archaeological Survey, Fayetteville.

Holliday, V.T.

1997 Paleoindian Geoarchaeology of the Southern High Plains. University of Texas Press, Austin. 
Hughes, Jack T.

1991 Prehistoric Developments on the Texas High Plains. Bulletin of the Texas Archeological Society, 60, pp. 1-56.

1962 Lake Creek: A Woodland Site in the Texas Panhandle. Bulletin of the Texas Archeological Society, 32, pp. 65-84.

Johnson, Eileen and Vance T. Holliday

2004 Archeology and Late Quaternary Environments of the Southern High Plains. In The Prehistory of Texas, Edited by Timothy K. Perttula. Texas A\&M University Press, College Station.

Justice, Glenn and John Leffler

2010 Ward Handbook ounty. Online. https://tshaonline.org/handbook/online/articles/hcw03. Accessed January 1 1, 2019.

Kelley, Jane Holden

1964 Comments on the Archeology of the Llano Estacado. Bulletin of the Texas Archeological Society, 35, pp. $1-18$.

Leffler, John

2010 Crane Handbook of County. Online. https://tshaonline.org/handbook/online/articles/hcc25. Accessed January 11, 2019.

Meltzer, D.J.

1987 The Clovis Paleoindian Occupation of Texas: Results of the TexasClovis Fluted Point Survey. Bulletin of the TexasArcheological Society 57:27-68.

Munsell Soil Color Chart (Munsell)

2005 Revised Edition. Macbeth Division of Kollmorgan Instruments Corporation.

Newcomb, W.W.

1961 The Indians of Texas: from Prehistoric to Modern Times. University of Texas Press, Austin.

Nationwide Environmental Title Research LLC (NETR)

2019 https://www.historicaerials.com/viewer. Accessed January 11, 2019.

Perttula, Timothy K. (editor)

2004 The Prehistory of Texas. Texas A \& M University Press, College Station.

Prikryl, D.J.

1990 Lower Elm Fork Prehistory: A Redefinition of Cultural Concepts and Chronologies along the Trinity River, North-central Texas. Report No.37. Austin: Office of the State Archeologist, Texas Historical Commission.

Smith, Julia Cauble

2010 Winkler Handbook of Texas Online. https://tshaonline.org/handbook/online/articles/hcw13. Accessed January 1 1, 2019. 
Soil Survey Staff, Natural Resources Conservation Service, United States Department of Agriculture (SSS NRCS USDA)

2019 Web Soil Survey. Available URL:

http://websoilsurvey.nrcs.usda.gov/app/WebSoilSurvey.aspx. Accessed January 1 1, 2019.

Turner, Ellen Sue and Thomas R. Hester

1993 A Field Guide to Stone Artifacts of Texas Indians. Second Edition. Texas Monthly Field Guide Series, Gulf Publishing Company, Houston.

United States Department of Agriculture - Natural Resources Conservation Service, Soil Survey Office (USDA-NRCS, SSO)

2008 General Soil Map of Texas. https://legacy.lib.utexas.edu/maps/texas/texasgeneral soil map-2008.pdf. Accessed January 11, 2019.

Watson, Lonnie

1978 Soil Survey of Ector and Crane Counties, Texas. United States Department of Agriculture Soil Conservation Service, Washington D.C.

Willey, Patrick S. and Jack T. Hughes

1978 The Deadman's Terrace Site, Archeology at MacKenzie Reservoir. Archeological Survey Report 24. Office of the State Archeologist, Texas Historical Commission, Austin.

Wormington, H.M.

1957 Ancient Man in North America. Popular Series, 4th Ed., Denver: Denver Museum of Natural History.

Wheat, Joe Ben

1972 The Olson-Chubbuck Site. A Paleo-Indian Bison Kill. Memoirs 26. Society for American Archeology, Washington, D.C.

Whitlock, V.H.

1970 Cowboy Life on the Llano Estacado. University of Oklahoma Press, Norman. 


\section{APPENDIX A: SURVEY RESULTS WITHIN CITY OF MIDLAND AND CITY OF COLORADO CITY PROPERTIES}

REMOVED FROM PUBLIC COPY 